\title{
Telling a Less Suspicious Story: Notes Toward a Non-Skeptical Approach to Legal/Cultural Analysis
}

\section{Paul Schiff Berman*}

Those of us who labor in academia-either in law or in the humanities - are, at a very basic level, storytellers. Both in my scholarly writing and in the classroom, I find that most of my effort is focused on constructing narratives of meaning from the complicated and multifaceted material that makes up our lived reality. Philosopher Wilhelm Dilthey wrote that "reality only exists for us in the facts of consciousness given by inner experience." But for every experience there is a wide range of possible meanings that can be assigned. And for every possible meaning there is a range of stories we can tell. As anthropologist Edward Bruner has pointed out, "If we write or tell about the French Revolution, for example, we must decide where to begin and where to end, which is not so easy, so that by our arbitrary construction of beginnings and endings we establish limits, frame the experience, and thereby construct it." ${ }^{\prime 2}$ On this view, "Every telling is an arbitrary imposition of meaning on the flow of memory... every telling is interpretive." 3 Thus, although we may not always be conscious of it, scholars are constantly engaged in the process of articulating a vision both of our culture and of the nature and shape of reality itself.

Moreover, I'm not sure that I at least am able to say definitively that any

* Associate Professor, University of Connecticut School of Law. This Essay was presented at a Symposium on Cultural Studies and Law held at Yale Law School and organized by Austin Sarat and Jonathan Simon. I am grateful to both for their comments and for providing me the opportunity to explore these ideas in such interesting company. In addition, this Essay was presented at the annual meeting of the Law \& Society Association in Miami, Florida and at the annual conference of the Working Group on Law, Culture, and the Humanities at Georgetown University Law Center, and I wish to acknowledge the numerous insights offered in response to the paper by audience members at both of these occasions. Finally, I thank Anne Dailey, Laura Dickinson, Martha Ertman, Jeremy Paul, Tom Morawetz, and Susan Silbey for helpful suggestions on earlier drafts.

1. Wilhelm Dilthey: SeleCted Writings 161 (H.P. Rickman ed. \& trans., Cambridge Univ. Press 1976).

2. Edward M. Bruner, Experience and Its Expressions, in THE ANTHROPOLOGY OF EXPERIENCE 3, 7 (Victor W. Tumer \& Edward M. Bruner eds., 1986).

3. Id. 
particular vision is necessarily the most "accurate." Certainly, if a scholar argued that the United States government consisted of Martians who were inhabiting the bodies of our national leaders, we might think that such a narrative was so removed from the everyday experience of most people that it was unhelpful. But, in the main, I find that there are a wide variety of critical stances available about any given subject and that it cannot necessarily be said that one approach is more "true" than another. ${ }^{4}$

If there are a range of plausible critical stances available about any given subject, then it is not inevitable that we choose one perspective over another. So how do I, as someone embarking on a project aimed at discussing law's role in American culture, choose the type of story I wish to tell? What sort of critical stance should I adopt, and what are the ramifications - political, psychological, spiritual - of that choice? These are the questions I wish to explore in this Essay. In the end, I will pursue the possibility of viewing law in an extremely sympathetic light, as a useful forum for discourse among multiple worldviews. Other scholars, of course, have provided more skeptical accounts of law's pervasive cultural influence. I will examine some of these accounts as well and offer reasons why, though much of this scholarship has been extremely useful, I wish to move in a different direction. But regardless of the critical stance one ultimately adopts, I hope that, simply by musing about these questions in a fairly personal way, I will encourage others to consider the ethical choices inherent in their own scholarship as well.

Nevertheless, before beginning I must first acknowledge that, merely by conceiving of one's critical perspective as a choice, I may have already committed myself to a particular point of view. For example, some might question just how free the choice of stories actually is. Our critical perspectives are, of course, influenced by many factors, including psychological predispositions, cultural and class backgrounds, concerns about career advancement, etc. Or, one might go even further and contend that the very idea of a free choice is illusory because embedded cultural and political forces may determine our choices without our conscious knowledge. ${ }^{5}$

Part of the point of this Essay, however, is to suggest that we might want to resist precisely this type of argument on the ground that such a perspective is ultimately disempowering, debilitating, and insufficiently useful from a pragmatic point of view. In addition, it seems reasonable to think that, at least as compared to most of the population, tenured academics are among the most free to choose their own critical stance. Nevertheless, I readily admit that the "choice" on which I focus may be

4. See, e.g., RENato Rosaldo, CUlture AND TRUTH: ThE REMAKING of Social ANalysis xviii (1989) (proclaiming that "classic modes of analysis, which in their pure type rely exclusively on a detached observer using a neutral language to study a unified world of brute facts, no longer hold a monopoly on truth. Instead, they now share disciplinary authority with other analytical perspectives").

5. See, e.g., Pierre Schlag, The Problem of the Subject, 69 TEX. L. REv. 1627 (1991). 
constrained in significant ways. Even with this caveat, though, I believe that it may still be useful to think self-reflectively about the critical perspectives we generally take and consider to what extent other possibilities exist. This exploration will necessarily be a personal one for each of us, but I think it is essential that we remember periodically to ask such questions about the kinds of stories we tend to tell.

In the generation of law and society research that emerged with the formation of the Law and Society Association, sociolegal scholars, building on the legal realist attack on formalism, told a story primarily about the possibility of social progress through law. Law was seen in instrumental terms as a means to a more just society, and scholars focused on the "gaps" between legal doctrine and legal practice in order to foster reform.

Over the past two decades, however, sociolegal scholars have become increasingly disenchanted with the reformist project. These writers, influenced by Michel Foucault and other postmodern theorists, have begun to see law not as an instrument for dispensing justice, but as a constitutive societal force shaping social relations, constructing meaning, and defining categories of behavior. Such a constitutive theory of law takes seriously Clifford Geertz's observation that law is not simply an instrument for enforcing a system of morality or justice but is also "part of a distinctive manner of imagining the real." emphasized that law cannot be distinguished from the rest of social life; rather, "law permeates social life, and its influence is not adequately grasped by treating law as a type of external, normative influence on independent, ongoing activities." As Paul Kahn has written recently, echoing a generation of critical legal scholars, "We experience the rule of law not just when the policeman stops us on the street or when we consult a lawyer on how to create a corporation. The rule of law shapes our experience of meaning everywhere and at all times. It is not alone in shaping meaning, but it is rarely absent."

As part of the move to view law as a constitutive force in social relations, many sociolegal scholars have chosen to go even farther and

6. ClIFFORD GEERTZ, Local Knowledge: Fact and Law in Comparative Perspective, in LOCAL KNOWLEDGE: FURTHER ESSAYS IN INTERPRETIVE ANTHROPOLOGY 167, 184 (1983).

7. Bryant G. Garth \& Austin Sarat, Justice and Power in Law and Society Research: On the Contested Careers of Core Concepts, in JUSTICE AND POWER IN SOCIOLEGAL STUDIES 1, 3 (Bryant G. Garth \& Austin Sarat eds., 1997) [hereinafter JUSTICE AND POWER].

8. See, e.g., Mark Kelman, A Guide to Critical Legal Studies 242-68 (1987); Robert W. Gordon, Critical Legal Histories, 36 STAN. L. REV. 57 (1984); Roberto Unger, The Critical Legal Studies Movement, 96 HARV. L. REV. 561 (1983).

9. Paul Kahn, The Cultural Study of LaW: Reconstructing Legal Scholarship 124 (1999). 
emphasize law's role as a pervasive form of social control. On this view, "Law constrains not by force but by creating the very categories of action that define social life." maintenance of inequality rather than its amelioration." "Accordingly, the focus of more recent sociolegal scholarship often involves uncovering how law's coercive power is inscribed in all legal discourse and practice.

This is certainly one possible story to be told about the constitutive power of law, but I wonder if there are others. For example, might we tell a story that emphasizes law's generative possibilities, one that envisions law not merely as an instantiation of embedded power, but as an activity that might have true intellectual, imaginative, ethical, and political value? Moreover, could we tell this story while still embracing a constitutive theory of law, and while refusing to return either to legal formalism or to the instrumental reformist vision of the first generation of law and society scholarship? And, if we can imagine such an alternative story, why might we choose to tell that story, rather than adopt the more familiar sociolegal focus on law as hegemonic discourse?

These questions form the basis of a larger project that I am just beginning, and so my aim in this Essay is to take a frankly impressionistic, unsystematic "first cut" at them. Such issues are of particular interest to me as an emerging scholar seeking a way both to embrace the antifoundational insights characteristic of postmodern thought and to acknowledge law's role as a discourse of cultural meaning, while at the same time trying to articulate a more optimistic and pragmatic story about law's power and potential.

But before attempting to articulate such a vision, it is necessary to examine the more skeptical story and to try to speculate about how that story came to be so dominant in cultural and sociolegal discourse. In this regard, it may be useful to reconsider Paul Ricoeur's famous analysis of the "hermeneutics of suspicion."12 Ricoeur discussed the work of three influential thinkers: Nietzsche, Marx, and Freud. According to Ricoeur, Nietzsche believed that human beings are in a constant state of deluding themselves that they actually possess foundational knowledge; Marx attempted to show that all societal institutions and ideological constructs were the product of economic relations; and Freud explained human behavior in terms of underlying unconscious impulses and desires. Thus, all three employed what Ricoeur called the hermeneutics of suspicion. According to Ricoeur, this approach is characterized by the desire to unmask, demystify, and expose the real from the apparent. Although

10. Nancy Reichman, Power and Justice in Sociolegal Studies of Regulation, in JUSTICE AND POWER, supra note 7, at 233, 250.

11. Garth \& Sarat, supra note 7, at 8.

12. PaUl Ricoeur, Freud and Philosophy: AN EsSAy on INTERPRETation 32-36 (Dennis Savage trans., Yale Univ. Press 1970). 
Ricoeur's ideas on this topic have been widely disseminated, I will review them briefly in Part One of this Essay.

It seems to me that the move in law and society scholarship away from a legal-realist-inspired reform agenda toward a focus on law as a pervasive and inescapable force in defining social relations can be viewed as an ongoing elaboration of this same hermeneutics of suspicion. In Part Two, I will sketch the evolution in sociolegal scholarship toward an ever more suspicious critical stance. Because it is beyond the scope of this Essay to attempt a systematic review of such scholarship, I will use as an illustrative case study a recent volume of essays, Justice and Power in Sociolegal Studies, edited by Bryant G. Garth and Austin Sarat. ${ }^{13}$ This collection exemplifies the constitutive view of law, and by examining several of the essays, we can perhaps begin to see how the skeptical approach operates more generally in contemporary sociolegal scholarship.

The hermeneutics of suspicion obviously has much to recommend it, and we have all learned a tremendous amount from the efforts of scholars to expose the pervasive discourse of power that may underlie lofty rhetoric, "neutral" philosophical systems, or even well-intentioned efforts at reform. In law, for example, sociolegal scholars have worked successfully not only to question the ability of the legal system to live up to its ideals, but also to challenge "the very ideals and principles that law claims for itself." 14 There can be little doubt that this suspicious stance has yielded substantial fruit. I emphasize this point because I do not want this Essay to be misread as yet another polemic against postmodern critical theory.

Nevertheless, the question remains: Do we always want to tell a story that seeks to challenge "the very ideals and principles that law claims for itself"? ${ }^{15}$ And, if we choose to tell a different story, must we jettison the

\footnotetext{
13. JUSTICE AND POWER, supra note 7.

14. Susan S. Silbey, Ideology, Power, and Justice, in JUSTICE AND POWER, supra note 7, at 272, 274.

15. This question raises, in a different context, the issue of "double consciousness" first identified by W.E.B. DuBois to describe the African-American experience. See W.E.B. DU BoIS, THE SoULS OF BLACK FOLK 3 (1903) ("The Negro is . . born with a veil, and gifted with second-sight. . . . [In] this double-consciousness ... [o]ne ever feels his two-ness, -American, a Negro; two souls, two thoughts, two unreconciled strivings; two warring ideals. ..."). Although we need not deny the coercive power of law, we may simultaneously recognize that law also provides a language and structure from which to construct alternative worlds. Ultimately, we might insist on such a double consciousness: recognizing both the persistence of oppression and the potentially generative nature of law.

In his seminal essay, Nomos and Narrative, Robert Cover argued that law functions in part "as a system of tension or a bridge linking a concept of a reality to an imagined alternative." Robert $M$. Cover, The Supreme Court, 1982 Term-Foreword: Nomos and Narrative, 97 HARV. L. REV. 4, 9 (1983). On this view, law is a language that allows us to discuss, imagine, and ultimately even perhaps generate alternative worlds spun from present reality. Thus, Cover envisioned law as that which connects "reality" to "alternity." Robert M. Cover, The Folktales of Justice: Tales of Jurisdiction, in NARRATIVE, VIOLENCE, AND THE LAW: THE ESSAYS OF ROBERT COVER 173, 176 (Martha Minow, Michael Ryan \& Austin Sarat 1992) (citing G. STEINER, AFTER BABEL 222 (1975)). If Cover's vision is correct, then law has enormous potential as a creative and transformative language. Building on this vision, my ultimate goal is to see whether one can use the idea of law as generative discourse to
} 
constitutive view of law altogether? In Part Three of the Essay, I explore two potential drawbacks of the hermeneutics of suspicion. First, such an approach may situate the writer (and perhaps the reader as well) in a superior position to those who are the objects of study. By unmasking ideologies and power dynamics unacknowledged by those participating in the systems being analyzed, the writer may imply that he or she is able to get beyond the mystification and see the situation more accurately than those caught "within" the system. ${ }^{16}$ Thus, for example, a critical scholar might attempt to show that, even when litigants report their satisfaction with the procedural justice system, such reports are unreliable because the litigants are unwittingly in the thrall of the legal system's dominance. Likewise, a critic who views law as a constitutive language may focus on the inherent power relations within that language, regardless of the subjective intentions of the participants who are actually engaged in the discourse. This type of analysis may, by its very nature, suggest that the writer has discerned a truth unavailable to those who are participating in the social practice. Such a perspective may not give sufficient value to the lived reality of those participants and may therefore provide a distorted picture of the social practice itself. ${ }^{17}$

Second, and perhaps even more importantly, relentless practice of the hermeneutics of suspicion may, over time, have a corrosive effect both on our psyches and on society as a whole. What does it mean for us to be consistently skeptical of all human efforts to make the world more just, more beautiful, or more joyful? In what ways might skepticism discourage such noble striving? To tell stories of beauty, of optimism, and of hope might be a profoundly important task in and of itself. And, even from the more earthbound perspective of political mobilization, a less suspicious story might actually be more effective at achieving social reform. As Richard Rorty has recently argued,

Those who hope to persuade a nation to exert itself need to remind their country of what it can take pride in as well as what it should be ashamed of. They must tell inspiring stories about episodes and figures in the nation's past-episodes and figures to which the

develop a more optimistic story about law's role. It seems to me that this story should, at the very least, sit alongside the suspicious one in our consciousness about law.

16. Thomas Morawetz, among others, has explored in detail the question of an "inside" versus an "outside" perspective in critical theory. See, e.g., Thomas Morawetz, Law as Experience: Theory and the Internal Aspect of Law, 52 S.M.U. L. REV. 27 (1999); Thomas Morawetz, Understanding Disagreement, the Root Issue of Jurisprudence: Applying Wittgenstein to Positivism, Critical Theory, and Judging, 141 U. PA. L. REV, 371 (1992) [hereinafter Morawetz, Understanding Disagreement].

17. Of course, the problems that may result from taking a "God's-eye view" are inherent in almost all scholarship, regardless of whether or not one takes a particularly suspicious critical stance. Nevertheless, a scholar who views the lived experience of participants empathetically may be less likely to discount that experience. In contrast, if one specifically sets out to unmask aspects of culture that are hidden to the participants, these problems may be more acute. 
country should remain true. ${ }^{18}$

Thus, from both a spiritual and a pragmatic standpoint, we may wish to adopt a sympathetic reading rather than a suspicious one, and to emphasize what is worthwhile in the efforts of people to construct ideas, systems, or principles, flawed though they might be. We must remember that, if the ideas of law and justice are inherently compromised by the practice of power and ideology, it may become more difficult even to envision a satisfactory response short of revolution.

Having discussed some limitations to the hermeneutics of suspicion, this Essay then offers notes toward a less skeptical approach to legal/cultural analysis. This approach builds on Ronald Dworkin's theory of how judges reach legal conclusions. ${ }^{19}$ According to Dworkin, the legal decisionmaking process is akin to a group of authors constructing a chain novel. In adding each new chapter, the author must interpret the work of the other authors in the preceding chapters so as to make of the overall shared enterprise the best work of art possible. Whether or not Dworkin is correct in his interpretation of judicial decision-making, I believe his analysis holds much promise as an attitude with which to undertake scholarly criticism. Rather than attempting to debunk, unmask, and demystify a particular legal or cultural practice and tell a story that makes the practice seem more oppressive than before, we might instead seek an interpretation that makes the best case on behalf of the practice, and that makes it into the best practice it can be, at least according to the values and philosophies of the critic. ${ }^{20}$

In conclusion, I offer one possible alternative story as an example of the type of less skeptical scholarship I have in mind. Significantly, this story also derives from the constitutive theory of law. And it resists the move, championed by some communitarian critics, to return to a pre-relativist world where one version of truth was to be considered authoritative. Rather, I emphasize law ${ }^{21}$ as a potentially generative site for the play of

18. RichaRd RoRTY, ACHIEVING OUR COUNTRY: LeFTIST THOUGHT IN TWENTIETH-CENTURY AMERICA 3-4 (1998).

19. See RONALD DWORKIN, LAW'S EMPIRE 225-75 (1986).

20. It is important to make clear at the outset that the distinction I am attempting to draw between hermeneutic approaches is not the same as the distinction between scholarship that criticizes a legal practice and scholarship that supports it. For example, one could imagine a law and economics scholar making an argument along the following lines: "The judge may have thought she was deciding the case based on $X$, but really she was promoting efficient economic relations, and we are all better off because she did so." Such an analysis would be suspicious as I am using the term because it seeks to unmask the practice being studied, even though it ultimately takes a position in favor of the decision. On the other hand, one could take a less skeptical approach by attempting to make the best possible case on behalf of a judicial decision, yet still conclude that the decision is incorrect. Thus, suspicious scholarship is not necessarily negative scholarship, nor is less suspicious scholarship necessarily positive.

21. When I refer to "law" in this Essay, I mean something very broad indeed. Not only do I refer to formal legal rules and procedures, but also to "quasi-legal" discourses and practices that sometimes straddle the law/entertainment boundary. See, e.g., Austin Sarat, Imagining the Law of the Father: 


\section{discourses and the encounter with the Other.}

The approach I suggest need not replace the more suspicious story altogether. Indeed, it should go without saying that there are multiple stories to be told, and any and all of them are likely to be useful at one time or another ${ }^{22}$ In addition, my discussion here only begins to raise the complicated question of how one decides, in any given circumstance, whether to adopt a suspicious or sympathetic approach. Nevertheless, I think that, simply by recognizing the possibility of alternatives, we will open a creative space for such a self-reflective question, which may be a positive development in and of itself.

Loss, Dread, and Mourning in The Sweet Hereafter, 34 LAw \& Soc'Y REV. 3, 5-10 (2000) (arguing that sociolegal scholars must "take on" cultural studies by considering how law exists in a world of film and television images); Alison Young, Murder in the Eyes of the Law, 17 STUD. L. POL. \& Soc'Y 31,31 (1997) (exploring how law "appears and reappears in the cinematic text"); see generally Richard K. Sherwin, Symposium, Picturing Justice: Images of Law \& Lawyers in the Visual Media: Introduction, 30 U.S.F. L. REV. 891 (1996). These include television court channels, legal talk shows, legal "thriller" novels and films, public memorials and ceremonies (such as the monument to victims of the Oklahoma City bombing or candlelight vigils to build community after hate crimes), and marches on Washington (such as the "Million Mom March" to lobby for stricter handgun regulations).

Even more broadly, my invocation of law is meant to refer to the often unnoticed practice of "law talk" in the society at large. By law talk, I mean the use of legal concepts in everyday language. Such talk includes abstract (and often inchoate) ideas of street justice, due process, civil disobedience, retribution, deterrence, and rights, all of which are frequently invoked both in public discussions and dinner-table conversations alike. Indeed, I deliberately use a conception of law aimed at expanding the law's generic constraints to encompass a broader spectrum of discourses talking in the "shadow" of official legal categories, but talking law nonetheless. See PATRICIA EWICK \& SUSAN S. SILBEY, THE COMMON PLACE OF LAW: STORIES FROM EVERYDAY LIFE 20 (1998) ("Legality . . operates through social life as persons and groups deliberately interpret and invoke law's language, authority, and procedures to organize their lives and manage their relationships. In short, the commonplace operation of law in daily life makes us all legal agents insofar as we actively make law, even when no formal legal agent is involved.").

The great variety of discourses that might be brought under the rubric of "law talk" not only attests to the conceptual power of law in the collective American consciousness, but also simultaneously underscores the elusiveness of the very concept of "law." For example, even relatively wellestablished forms of "alternative" dispute resolution, such as mediation and arbitration, are accepted by many legal practitioners as legitimate quasi-legal mechanisms; to others, however, they are viewed as antithetical, even subversive to canonical law practice. This is merely one example of the way in which a narrow definition of "law" can serve as a hegemonic arbiter of what counts as sanctioned legal practice. Thus, a methodical definition of "law" is not only unlikely to be satisfying, but it also may tend to privilege certain understandings of law over others. In any event, attempting such a definition is a project far beyond the scope of this Essay. Accordingly, although I refer to "law" and "legal" discourse liberally, I do so with invisible quotation marks around them in order to acknowledge their broad interpretation and application. $C f$. id. at 22 (choosing to use the term "legality" rather than "law" to describe a broader set of "meanings, sources of authority, and cultural practices that are commonly recognized as legal, regardless of who employs them or for what ends").

22. My focus on "usefulness" as the criterion for choosing among critical approaches echoes some of the core insights of pragmatist philosophy. See RICHARD RORTY, Truth Without Correspondence to Reality, in PHILOSOPHY AND SOCIAL HOPE 23, 27 (1999), ("Pragmatists-both classical and 'neo-'-do not believe that there is a way things really are. So they want to replace the appearance-reality distinction by that between descriptions of the world and of ourselves which are less useful and those which are more useful."). For further discussion of pragmatism, critical theory, and law, see Morawetz, Understanding Disagreement, supra note 16, at 443-49. See generally THE ReVIVAL OF PRAGMatiSM (Morris Dickstein ed., 1998); Steven D. Smith, The Pursuit of Pragmatism, 100 Yale L.J. 409 (1990); Peter D. Swan, Critical Legal Theory and the Politics of Pragmatism, 12 DALHOUSIE L.J. 349 (1989); Symposium, The Renaissance of Pragmatism in American Legal Thought, 63 S. CAL. L. REV. 1569 (1990). 
For myself, I ultimately choose to tell a story that may help remind us what is best about our nation's legal environment, and instill a sense of optimism about our ongoing shared enterprise. I neither expect nor desire that all scholars embrace the same perspective. Rather, I suggest only that our critical stance is, in part, an ethical choice and that we should each consider the subtle but significant ramifications of the types of stories that we tell.

\section{PAUl Ricoeur AND THE HeRmeneutics OF SUSPICION}

Paul Ricoeur speaks not of stories but of hermeneutics. Yet his inquiry is similar: What are the methodological principles we use to interpret and describe reality? Although it is beyond the scope of this Essay to attempt a comprehensive analysis of Ricoeur's discussion of hermeneutic styles, I believe it may be useful to invoke Ricoeur's categories briefly, because they can provide a framework for considering trends in sociolegal scholarship.

Ricoeur contrasts two different "poles" among hermeneutic styles. At one pole, "hermeneutics is understood as the manifestation and restoration of . . . meaning." ${ }^{23}$ At the other pole, hermeneutics is "understood as a demystification, as a reduction of illusion." ${ }^{24}$ It is not entirely clear to me precisely what Ricoeur means by these two categories. Nevertheless, I understand a hermeneutics of faith to be one that treats the object of study as possessing inherent meaning on its own terms. In contrast, the hermeneutics of suspicion seeks to expose societal practices as illusory edifices that mask underlying contradictions or failures of meaning. I will return to the first pole in Part Four of this Essay, but for now I wish to focus on the hermeneutics of demystification and suspicion.

Ricoeur locates in the work of Nietzsche, Marx, and Freud the central hallmarks of this suspicious approach. He argues that each of these thinkers makes "the decision to look upon the whole of consciousness primarily as 'false' consciousness." ${ }^{25}$ Ricoeur sees this perspective as an extension of Descartes' fundamental position of doubt at the dawn of the Enlightenment. According to Ricoeur, "The philosopher trained in the school of Descartes knows that things are doubtful, that they are not such as they appear; but he does not doubt that consciousness is such as it appears to itself; in consciousness, meaning and consciousness of meaning coincide." 26 The hermeneutics of suspicion takes doubt one step farther, by distrusting even our perceptions.

This suspicious position questions the so-called "correspondence

\footnotetext{
23. RICOEUR, supra note 12, at 27.

24. Id.

25. Id. at 33 .

26. Id.
} 
theory" of truth. As we go through our lives, most of us generally assume that our mental perceptions accord with reality because we believe we have direct access to reality through our senses or through reason. This is the legacy of the Enlightenment, the "answer" to the fundamental Cartesian doubt. But the hermeneutics of suspicion maintains that human beings create false truths for themselves. Such false truths cannot be "objective" because they always serve some interest or purpose.

By discovering and revealing those interests or purposes, suspicious analysis seeks to expose so-called "false consciousness" generated through social ideology or self-deception. False consciousness may arise in many different ways. Nietzsche looked to people's self-deceit in the service of the "will to power." Marx focused on the social being and the false consciousness that arises from ideology and economic alienation. Freud approached the problem of false consciousness by examining dreams and neurotic symptoms in order to reveal hidden motivations and desires. Thus, "the Genealogy of Morals in Nietzsche's sense, the theory of ideologies in the Marxist sense, and the theory of ideas and illusions in Freud's sense represent three convergent procedures of demystification."27

Although these three "masters of suspicion" aim to destroy false consciousness, they do so in the service of greater consciousness. For all three, there is some better, healthier perspective to which we should aspire. As Ricoeur points out, they are attempting to "clear the horizon for a more authentic word, for a new reign of Truth." 28

This move is significant, and it is perhaps what allows us to characterize these three thinkers as modern, rather than postmodern, critics. Although they attack false consciousness, they cling to the possibility of a "truer" consciousness. Nietzsche wants to recapture the meaning of the will to power by meditating on the deceptions of "superman," "eternal return," and "Dionysus." 29 Marx argues for a "conscious insight" that will counteract the mystification of false consciousness. ${ }^{30}$ And, as Ricoeur explains, "What Freud desires is that the one who is analyzed, by making his own the meaning that was foreign to him, enlarge his field of consciousness, live better, and finally be a little freer and, if possible, a little happier." ${ }^{, 31}$

Thus, the hermeneutics of suspicion as practiced by these three modernist thinkers involves demystifying illusion and fable, but then replacing that false consciousness with something "better" and "truer." Postmodern thinkers take this hermeneutics of suspicion one step farther by questioning whether the "true" consciousness that emerges through

27. Id. at 34 .

28. Id. at 33 .

29. See id. at 35 .

30. See id. at 34-35.

31. Id. at 35 . 
demystification is any truer than the "false" consciousness that existed previously. On this view, Nietzsche, Marx, and Freud, no matter how suspicious they were, can still be characterized as part of the Enlightenment project. This project, as David Harvey has written, "took it as axiomatic that there was only one possible answer to any question. From this it followed that the world could be controlled and rationally ordered if we could only picture and represent it rightly." ${ }^{32}$ Likewise, Nietzsche, Marx, and Freud offered particular forms of order that they advocated as the more accurate picture of the world.

By contrast, in his seminal work, The Postmodern Condition, JeanFrançois Lyotard defines postmodern existence as the inability to believe in any such "metanarratives." 33 And, in his explication of metanarratives, Lyotard includes as an example Marx's political story of class conflict and revolution. ${ }^{34} \mathrm{He}$ could easily have included the metanarratives asserted by Nietzsche and Freud as well. Indeed, Jean Baudrillard makes the point starkly when he writes that, whereas modernity is concerned with "the immense process of the destruction of appearances . . . in the service of meaning," post-modernism addresses the "immense process of the destruction of meaning, equal to the earlier destruction of appearances. ${ }^{\prime 35}$

This is a kind of "hyper-suspicion." From this perspective, all explanatory stories are contingent, even those offered by the skeptical critic. It is this constant questioning that leads some people to view such postmodern suspiciousness as nihilistic or paranoid. ${ }^{36}$ For these critics of postmodernism, it is one thing to undertake a process of dismantling that also provides for rebuilding. It is quite another to take a stance "where the point is precisely to dismantle with no ground left, but only a multiplicity of standpoints which amounts to no standpoint - an everywhere which is nowhere." ${ }^{37}$ On this view, "The enabling suspicion of the older tradition is extended and intensified into paranoia—and thus becomes disabling." 38

32. DaVId HaRvey, THE CONDITION OF POSTMOdERNITY: AN ENQUIRY INTO THE ORIGINS OF Cultural Change 27 (1990).

33. See Jean-François Lyotard, The Postmodern Condition: A RePort on KNowledge, at xxiv (Geoff Bennington \& Brian Massumi trans., Univ. of Minnesota Press, 1984) (1979).

34. See id.

35. JEAN BaUdRILlaRd, SimUlacra aNd Simulation 160-161 (Sheila F. Glaser trans., Univ. Mich. Press 1994).

36. See, e.g., Paul D. Carrington, Of Law and the River, 34 J. Legal EduC. 222, 227 (1984); Martha C. Nussbaum, The Professor of Parody, NEw RePuBliC, Feb. 22, 1999, at 37.

37. Linda Fisher, Hermeneutics of Suspicion and Postmodern Paranoia: Psychologies of Interpretation, 16 PHILOSOPHY AND LITERATURE 106, 112 (1992).

38. Id.; accord RichaRd K. SHERWIN, When LAW GOES PoP: THE VANishing Line Between LAW AND POPULAR CULTURE 129 (2000) ("[I]n the end the skeptical postmodern is left with nothing more than endless play and detached irony"); JAMES B. TWITCHELL, CARNIVAL CULTURE 51 (1992) ("What characterizes the condition of culture since World War II is . . . that now we have more signs than referents, more images than meanings that can be attached to them. The machinery of communication often communicates little except itself-signs just refer to each other, creating a 'simulacra' of reality."). 
I do not share this view, although I am sympathetic to its concerns. It is undoubtedly the case that some postmodern scholars, both in law and the humanities, have focused so much on dismantling that they are left with no constructive story to tell. However, I do not think that nihilism is a necessary feature of postmodern thought. ${ }^{39}$ Indeed, I will argue in Part Five that, by recognizing the existence of multiple stories, all with potentially legitimate claims to truth, we can focus on the play of opposing discourses and the creative possibilities that arise from conversation among competing narratives. The view from postmodernism need not be so bleak. ${ }^{40}$ Nevertheless, it is clear that the basic approach of both modern and postmodern critics in the twentieth century has been characterized by a general suspicion about truth claims.

\section{ThE HERMENEUTICS OF SUSPICION AND SOCIOLEGAL SCHOLARSHIP}

\section{A. An Overview of Trends}

In legal scholarship, we might view some of the key theoretical movements in the twentieth century as a similar progression of the hermeneutics of suspicion. First, scholars attacked the purportedly neutral principles underlying legal doctrine in order to spark progressive reform. Next, they turned to the question of whether law reform could achieve the aims of justice. And finally, they began to envision law as a pervasive and inescapable form of social control. As a way of summarizing these moves, I will consider a collection of essays published in 1998, Justice and Power in Sociolegal Studies. Because the editors and many of the contributors to the collection are leading figures in contemporary law and society scholarship, the volume provides a useful snapshot of current perspectives in the field as well as a "native" account of scholarly trends over the past several decades authored by two active participants, Bryant G. Garth and Austin Sarat.

In the first decades of the twentieth century, legal realists asserted that legal doctrine was inherently indeterminate, and therefore decisions about

39. My hopefulness about the possibilities that exist within postmodern legal discourse perhaps distinguishes this Essay from earlier attacks on critical legal theory. For example, in his well-known essay, The Death of the Law?, Owen Fiss criticized the "negativism" of critical legal studies and argued for the building of social and political movements reminiscent of the 1960s that would help foster "a belief in public values." Owen Fiss, The Death of the Law?, 72 CORNELL L. REV. 1, 14-15 (1986). In many respects, my aims are similar to Fiss's. He too sought "[a]n appreciation of law as a generative force of our public life," $i d$. at 15 , and identified the skeptical stories of critical legal theory as potentially destructive of that aim. Unlike Fiss, however, I do not pin my hopes on a revival of the political activism of the 1960 s (though I would certainly be pleased to see the return of such an activist spirit). Nor do I decry critical theory as inherently destructive. Rather, I suggest that the very antifoundational insights of postmodern theory that Fiss criticizes might be used to open an imaginative space for understanding law in ways that might generate the public values Fiss seeks.

40. See SHERWIN, supra note 38, at 128-33 (distinguishing between "skeptical" and "affirmative" postmodernism). 
contested doctrinal issues were always decided based on non-doctrinal factors. Law and society research in the 1960s extended this critique, pushing a progressive agenda that sought to use law instrumentally to achieve distributional justice. As described by Garth and Sarat in the Introduction to Justice and Power in Sociolegal Studies, "At this stage in the development of law and society research, there was a taken-forgranted understanding of the nature of justice and an unembarrassed commitment to the project of using social research to promote justice through law." ${ }^{41}$ Thus, scholars focused on the gap between "law on the books" and "law in action" in order to suggest better ways of implementing a just legal order. For example, Garth and Sarat cite an American Bar Foundation Survey of Criminal Justice in the 1950s and 1960s finding that the exercise of discretion among regulators and the police was one factor preventing the criminal justice system from operating consistently with the progressive ideals being articulated by the Supreme Court in that era. ${ }^{42}$ The focus, in this and other "gap studies," was to identify and explain deviations from the regulatory ideal. However, "[i]mplicit in most of this research was the assumption that the state regulatory policies, like the goals of the criminal justice system, represented an appropriate starting point for a researcher strongly committed to social justice." 43

The legal realist critique and sociolegal gap studies can be viewed as equivalent to the modernist version of the hermeneutics of suspicion described by Ricoeur. Just as Nietzsche, Marx, and Freud (in Ricoeur's view) attacked false consciousness but remained committed to the existence of a "truer" consciousness, so too did legal realists challenge the truth claims of legal formalism, while remaining committed to using law instrumentally to achieve justice. ${ }^{44}$ Similarly, early law and society scholarship employed the hermeneutics of suspicion to expose the failure of specific legal efforts to enact meaningful reform, but did not question the fundamental assumption that the legal order was an appropriate site for seeking justice.

The next move in the progression toward greater suspicion came from those (to use Garth and Sarat's taxonomy) who criticized gap studies and "raised questions about the ability of the liberal state, even in the best of times and with the best intentions, to realize social justice. ${ }^{945}$ Here, law

41. Garth \& Sarat, supra note 7 , at 4 .

42. See id. at 4-5.

43. Id. at 5 .

44. See Richard Michael Fischl, Some Realism About Critical Legal Studies, 41 U. MIAMI L. REV. 505, 521 (1987): ("Realism undertook its rule-debunking program in the service of exposing the law for what it really was: social policymaking. But the Realists did not intend to leave the Emperor naked. The law's 'ought' could be... discovered by a fact-sensitive adjudication overtly and consciously informed by the methods of social science.")

45. Garth \& Sarat, supra note 7 , at 6 . 
was still seen in instrumental terms, but as a force that actually thwarts meaningful reform. Thus, Garth and Sarat cite the work of scholars who, they say, viewed "the entire regulatory effort [as] some kind of hoax, unlikely ever to contribute to the progressive goals implicit in early enthusiasm for regulation." 46 These scholars expressed "skepticism about the power of litigation to promote social change, about claims of right generally, about the helpfulness of due process hearings for welfare recipients, the usefulness of consumer rights, the proliferation of alternative dispute mechanisms, and the autonomy of the legal profession." ${ }^{477}$

Here we see the hermeneutics of suspicion deployed in order to expose not only the failure of law reform but also the very impossibility of law reform. This perspective questions the power of even well-intentioned people to bring us closer to justice through law. As Garth and Sarat describe, "Loss of confidence in research-inspired progressive legal reform led law and society scholars away from the strategy of 'delivering legality' as a way of delivering justice." 48 It is in this period that we also see the emergence of critical legal studies scholarship challenging the classic doctrines of American law and legal education, including contracts, torts, and corporations, as well as antidiscrimination and labor law. Some analyses argued that appeals to reason or principle are inevitably incoherent and that the resolution of legal questions is therefore inherently political. ${ }^{49}$ Others focused on the suppression of alternative values by dominant ideologies. ${ }^{50}$ Still others argued that legal education was an indoctrination of individuals into a dominant elite.$^{51}$ Finally, some critical scholars challenged assumptions underlying communication itself by claiming that all meaning is ultimately determined by the listener/reader. ${ }^{52}$

46. Id.

47. Id. (citing Gerald Rosenberg, The hollow Hope: Can Courts Bring about Social Change? (1991); JOEl HANDLER, SOCIAL MOVEMENTS AND THE LEGAL SYSTEM (1978); JOHN

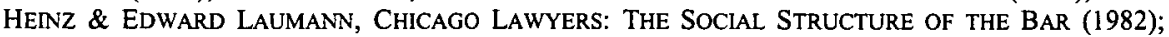
Robert Nelson, Partners With PoWer: Bureaucracy, Professionalism, and Social Change

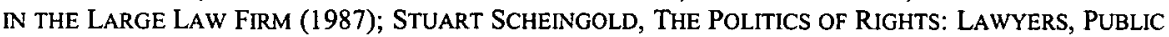
POLICY, AND POLITICAL CHANGE (1974); Richard L. Abel, The Contradictions of Informal Justice, in 1 The Politics of INFORMAL JustiCE 267 (Richard L. Abel ed., 1982); Marc Galanter, Why the "Haves" Come Out Ahead: Speculations on the Limits of Legal Change, 9 LAW \& SOC'Y REV. 95 (1974); Stewart Macaulay, Lawyers and Consumer Protection Laws, 14 LAW \& Soc'y Rev. 115 (1979)).

48. Garth \& Sarat, supra note 7, at 6-7 (citation omitted).

49. See, e.g., The Politics of Law: A Progressive CrITIQue (David Kairys ed., 1982).

50. See, e.g., Gerald E. Frug, The Ideology of Bureaucracy in American Law, 97 HARV. L. REV. 1277 (1984); Mary Jo Frug, Rereading Contracts: A Feminist Analysis of a Contracts Casebook, 34 AM. U. L. REV. 1065 (1985); Duncan Kennedy, Form and Substance in Private Law Adjudication, 89 HARV. L. REV. 1685 (1976).

51. See, e.g., KelmaN, supra note 8; Duncan Kennedy, Legal Education As Training for Hierarchy, in THE POLITICS OF LAW, supra note 49.

52. In 1988 Sanford Levinson and Steven Mailloux observed that, in light of "ambiguities of interpretation, many legal theorists have substituted for the hermeneutics of objective interpretation 
These moves exemplify a further elaboration of the suspicious approach. There is again a distrust of stated rationales and a desire to expose false consciousness. But now, under the influence of postmodern critical theory, we begin to find a new level of unmasking-not merely that one particular justice claim is ineffective, but that any justice claim is inevitably compromised by the legal language and institutional context in which it is framed. In the ongoing discourse between law and power, power was beginning to triumph as the fundamental "truth" to be revealed through critical (i.e. suspicious) scholarship.

Finally, Garth and Sarat identify the move toward a constitutive, rather than an instrumental, vision of law. Such an approach focuses not on how law might serve progressive goals, but instead on how law works within a society to help shape social relations. "The study of ideology and legal consciousness, in particular, became part of the quest for an understanding of this side of law's power." 53

A constitutive view of law sees legal discourse, categories, and procedures as a framework through which individuals in society come to apprehend reality. Thus, law is not merely a coercive force operating externally to affect behavior and social relations; it is also a lens through which we view the world and actually conduct social relations. On this view, "[L]aw shapes society from the inside out by providing the principal categories in terms of which social life is made to seem largely natural, normal, cohesive, and coherent." 54 Clifford Geertz perhaps provided a manifesto for the constitutive view in 1983:

[L]aw, rather than a mere technical add-on to a morally (or immorally) finished society, is, along of course with a whole range of other cultural realities ... an active part of it... Law ... is, in a word, constructive; in another constitutive; in a third, formational. ${ }^{55}$

Law, with its power to place particular things that happen ... in a general frame in such a way that rules for the principled management of them seem to arise naturally from the essentials of their character, is rather more than a reflection of received wisdom or a technology of dispute settlement. ${ }^{56}$

For at least the past fifteen years, sociolegal scholars have largely pursued a constitutive vision of law and therefore have treated law as (1) a

what Gerald Graff has termed a "hermeneutics of power," where one emphasizes the political and social determinants of reading texts one way as opposed to another." INTERPRETING LAW AND LITERATURE, at xiii (Sanford Levinson \& Steven Mailloux eds., 1988) (quoting Gerald Graff, Textual Leftism, 49 PARTISAN REV. 566 (1982)).

53. Garth \& Sarat, supra note 7 , at 8 (citation omitted).

54. Austin D. Sarat, Redirecting Legal Scholarship in Law Schools, 12 YaLE J. L. \& HuMAN. 129, 134 (2000) (reviewing KAHN, supra note 9), .

55. GEERTZ, supra note 6, at 218 .

56. Id. at 230 . 
belief system that helps to define the roles of individuals within society; (2) a system of organization that determines societal roles; and (3) a language for conceptualizing reality, mediating social relations, and defining behavior. Following Geertz, they have deployed various interpretive methods to study the "webs of signification"57 found within law.

Significantly, taking a constitutive view of law need not commit one to the hermeneutics of suspicion. Indeed, in the final Part of this Essay, I will attempt to point toward a less skeptical constitutive approach. Nevertheless, as Garth and Sarat point out, many of those who have adopted a constitutive view of law's power have focused on law as a particularly pervasive form of social control. "Studying the power of law as social control has led scholars to consider the mechanisms through which liberal legality works to limit our conceptions of justice as well as our efforts to promote social change." ${ }^{8}$ Indeed, the deployment of the hermeneutics of suspicion has become so complete that it is difficult for its adherents to remain committed to any instrumental social reform task. As Garth and Sarat observe, "research on law's constitutive power generally shows how law disciplines potential challengers to the social order rather than serving to promote change and reform." 59 From such a perspective, even the idea of justice is unmasked and demystified. "Justice becomes at best an external, political critique-and otherwise an inevitable disciplinary ally of law's hegemony." written, "[T] $]$ he ideals and principles that legal institutions announce, even though they fail to support them, are part of how legal institutions create their own power and authority." 61

Thus, the progression of sociolegal scholarship charted by Garth and Sarat can be seen as stages in the further elaboration of a hermeneutics of suspicion. As they acknowledge, "Recognition of law's hegemony and its constitutive power [has] undermined the optimism of the vision of 'social justice through law' that animated so much early scholarship."62 And, now that many sociolegal scholars take as given the idea that law is constitutive, it is not surprising to see a substantial body of scholarship predicated on the idea that law is fundamentally a language and structure of social control and a means by which entrenched power relations are constructed and legitimized. Even the more recent turn in sociolegal scholarship to a focus on "agency"- the ways in which individuals contest

57. Id. at 182 (quoting A.M. HOCART, KINGS AND COUNCILlORS: AN ESSAY IN THE COMPARATIVE ANATOMY OF HUMAN SOCIETY 128 (1970)).

58. Garth \& Sarat, supra note 7 , at 8 .

59. Id. at 9 .

60. Id. at $9-10$.

61. Silbey, supra note 14 , at 274 .

62. Garth \& Sarat, supra note 7, at 10. 
and resist legal categories - tends to build from the assumption that law inevitably operates as a force of power, thereby engendering the resistance.$^{63}$ Moreover, although I have focused on the development of law and society scholarship in particular, the basic scholarly approach will no doubt be familiar to those who identify with movements in feminist legal theory, critical race theory, and others. Employing the hermeneutics of suspicion, these scholars too have attempted to uncover the ideological biases in legal categories, the stories excluded or distorted through law, and the inequities inherent in legal discourse, procedure, and adjudication. ${ }^{64}$ As Garth and Sarat observe, "many scholars would say that they now study power, not justice." ${ }^{\circ 5}$

\section{B. Specific Scholarly Projects}

So far, the discussion has been fairly abstract. In this Section, therefore, I will explore how the hermeneutics of suspicion plays out in several articles. My aim is neither to criticize these projects nor show the ways in which they are wanting. Indeed, I have deliberately attempted to select strong examples of suspicious scholarship in order to avoid the accusation that I am setting up a straw man. Thus, I attempt to identify some of the consequences of a suspicious approach even in works that make useful contributions.

Turning again to Justice and Power in Sociolegal Studies, I begin by looking at Carol J. Greenhouse's essay in that volume, Figuring the Future: Issues of Time, Power, and Agency in Ethnographic Problems of Scale. ${ }^{66}$ Greenhouse focuses on two concepts, diversity and community, and seeks to describe law's role with regard to both. She offers two case studies. First, she discusses press coverage of the 1992 violence in Los Angeles after the verdict in the trial of four police officers accused of beating Rodney King. Then, she analyzes the Supreme Court's decision in Brown v. Board of Education, ${ }^{67}$ as well as the text of three major federal

63. See, e.g., Sarat, supra note 54 , at 140 ("Contests over meaning in courts or communities .. become occasions for [sociolegal scholars to observe] the play of power. Meanings that seem natural, or taken-for-granted, are described as hegemonic, but because the construction of meaning through law is, in fact, typically contested, scholars show the many ways in which resistance occurs.") (citation omitted). For examples of such work, see SALLY ENGEL MERRY, GETTING JUSTICE AND GETTING EVEN: LEGAL CONSCIOUSNESS AMONG WORKING-ClASS AMERICANS (1990); BARBARA YNGVESSON, VIRTUOUS CITIZENS, DisRuPTIVE SUBJECTS: ORder AND COMPLAINT IN A NEW ENGLAND COURT (1993). For a further discussion of the agency critique, see infra notes $86-90$ and accompanying text.

64. Surprisingly, even interdisciplinary scholars in public choice theory and law and economics, who are not generally associated with a progressive agenda, employ a "watered-down" hermeneutics of suspicion by positing that self-interest (rather than stated values) is the "true" explanation of political and social processes. See also supra note 20.

65. Garth \& Sarat, supra note 7, at 10.

66. Carol J. Greenhouse, Figuring the Future: Issues of Time, Power, and Agency in Ethnographic Problems of Scale, in JUSTICE AND POWER, supra note 7, at 108.

67. 347 U.S. 483 (1954). 
civil rights statutes enacted from 1964 to $1991 .{ }^{68}$

Starting from these two case studies, there are a number of different stories Greenhouse might have told about the role of law with regard to diversity and community. For example, she might have discussed the way in which the civil rights laws attempted to construct a more inclusive conception of community by providing more space for diversity in society. Or she could have discussed the circumstances under which civil rights lawsuits might provide a community forum for discussion among diverse voices. Or she might have talked about the ways in which law could speak usefully about diversity or help to construct community.

But Greenhouse instead chooses to tell a story that equates the various civil rights statutes with the police crackdowns in Los Angeles. She acknowledges that the two case studies seem to be opposites: one "involves massive disruption and violence," and the other "involves the legal poetics of equality." ${ }^{\prime \prime 9}$ But, she argues that the differences between the two case studies

are superficial. In fact, they both associate diversity axiomatically with violence, and both associate diversity with a corollary need for active legal intervention. The interventions differ in form-police action in Los Angeles and judicial and legislative action in the civil rights context - but not in their operative premise that diversity is intrinsically uncivil without the intervention of the law. ${ }^{70}$

It is important to recognize how the hermeneutics of suspicion works here. We might at first think that civil rights statutes are an attempt to acknowledge diversity and protect it by preventing discrimination. But Greenhouse attempts to demystify the statutes. She reads them to be as hostile to the idea of diversity as was the newspaper coverage of the Los Angeles riots that focused on the supposedly inherent volatility of multiethnic neighborhoods. And she argues that law is not so much about mediating the effects of diversity in order to foster community, as about claiming the power to transform diversity into civility.

Greenhouse views the civil rights statutes as an assertion of state power, an attempt to "construct 'community' around the central axis of the state's role in the management of diversity in physical space." $" 71$ Thus, a disorderly community "call[s] forth the law's coercive powers of physical social control." $" 2$ But an orderly community that resorts to courts rather than violence is also squelching diversity, by invoking the state as mediator among diverse groups that are "implied as being ordinarily

68. See Civil Rights Act of 1964, 78 Stat. 241 (1964); Voting Rights Act of 1965, 79 Stat. 437 (1965); Civil Rights Act of 1991, 105 Stat. 1071 (1991).

69. Greenhouse, supra note 66 , at 114.

70. Id.

71. Id. at 125 .

72. Id. 
inimical to each other."73

Greenhouse also focuses on the constitutional basis for the federal civil rights statutes. Historically, the ability of Congress to enact such statutes has been justified as an exercise of its power to regulate interstate commerce. Although most observers would agree that justifying civil rights legislation as a regulation of commerce is counterintuitive, there are historical and jurisprudential reasons that such an approach proved to be a pragmatic strategy to persuade the Supreme Court of the constitutionality of the statutes. ${ }^{74}$ Greenhouse chooses to tell a different story, however. From this jurisprudential choice she makes the observation that, in the civil rights law, "commerce emerges as an ongoing materialization of the state's agency that ... takes up its vigil over the public space through law enforcement." ${ }^{75}$ In Greenhouse's account, the interstate commerce rationale is itself somewhat suspicious. She argues that the civil rights statutes "imply ... that the colonization of the future will be financed with capital borrowed from the meanings of difference." 76

Thus, Greenhouse's story subverts the idea that the civil rights statutes represent any kind of advance toward justice or societal tolerance for diversity. Instead, she argues that in both the fears about urban violence and the enactment of civil rights legislation, "the state's centrality in the public management of 'diversity,' the materialization of that agency in investment and commerce, and the commoditization of identity emerge as inextricably linked ideas and social processes." ${ }^{.77}$ Moreover, she rejects the idea that the concept of "community" might even provide a meaningful aspirational goal. Rather, she views "community" as merely a rhetorical conceit that is "deliberately reworked as legal and political strategies by architects and adversaries of change." 78

\footnotetext{
73. Id.
}

74. Indeed, as many critics have observed, the clause of the Fourteenth Amendment guaranteeing the "privileges or immunities of citizens of the United States" would seem to be a more likely source for Congress' power to enact civil right legislation. The Supreme Court construed this language so narrowly in the Slaughterhouse Cases, 83 U.S. 36 (16 Wall.) (1872), however, that proponents of such legislation were forced to look elsewhere to justify congressional power. For further discussion of more recent calls to overrule the Slaughterhouse Cases, see, e.g., CHARLES L. BLACK, JR., A NEW BIRTH OF FREEDOM: HUMAN RIGHTS, NAMED, AND UNNAMED 146-48 (1997); JoHN HART Ely, DEMOCRACY AND DISTRUST: A THEORY OF JUDICIAL REVIEW 28-30 (1980); DAVID A.J. RICHARDS, CONSCIENCE AND THE CONSTITUTION: HISTORY, THEORY, AND LAW OF THE RECONSTRUCTION AMENDMENTS 199-232 (1993); LAURENCE H. TRIBE, AMERICAN CONSTITUTIONAL LAW $\$ \S 7-2$ to 7-4 (1978); Akhil Reed Amar, The Bill of Rights as a Constitution, 100 YALE L.J. 1131, 1149 (1991); Richard L. Aynes, On Misreading John Bingham and the Fourteenth Amendment, 103 Y ALE L.J. 57, 103-04 (1993); Philip J. Kurland, The Privileges or Immunities Clause: Its Hour Come Round at Last?, 1972 WASH. U. L.Q. 405 (1972); William Winslow Crosskey, Charles Fairman, "Legislative History," and the Constitutional Limitations on State Authority, 22 U. CHI. L. REV. 3, 3-10 (1954). See generally MiCHAEl Kent CuRTIS, No STATE SHALl ABRIDGE: THE FourteENTH AMENDMENT AND THE BILL OF RIGHTS 216-20 (1986).

75. Greenhouse, supra note 66 , at 124 .

76. Id.

77. Id. at 127 .

78. Id. 
These are provocative ideas, and I do not here wish to take issue with any of Greenhouse's contentions. Instead, I note only the choice of stories. What are the narratives that we take from the essay? Federal civil rights statutes are ultimately hostile to diversity because they implicitly associate diversity with violence. These statutes inevitably inscribe the state's role in managing and enforcing the transformation of diversity into civility. Such state control is linked to commerce, commoditization, and colonization. And "community" is a strategic construct used to enforce these norms of civility and control. Thus, Greenhouse effectively challenges our faith in the aspirational goals of civil rights as diversityprotecting, community-building, or civility-enhancing.

My second example of the way in which sociolegal scholarship chooses among multiple available stories comes from the study of procedural justice. Tom R. Tyler's essay, Justice and Power in Civil Dispute Processing ${ }^{79}$ provides an overview of the substantial literature in this area. The literature consists largely of empirical studies about litigant satisfaction with various dispute resolution mechanisms. "Instead of evaluating litigation experiences against objective criteria specifying desirable features of procedures or outcomes, experiences are evaluated in terms of the subjective experiences of the litigants." 80

Such studies use interviews with disputants to examine the degree to which people care simply about "winning," and the extent to which they care about other elements of the dispute resolution process, including notions of fair procedure. For example, one study of civil litigation ${ }^{81}$ reached two basic conclusions. First, just looking at outcome turns out to be a poor predictor of litigant satisfaction. "Whether assessed in terms of length of time to case resolution (delay), costs to the litigant, and/or amount won or lost, objective indicators do not explain much about people's postlitigation feelings." 82 Second, litigant satisfaction is closely correlated with subjective perceptions of whether the process was just. Moreover, the factors that influenced such a determination, rather than being related to outcome, focused more on process issues such as whether the participant had the opportunity to address the decision maker, whether the decision maker appeared to be honest, and whether the participant was treated with dignity and respect. ${ }^{83}$

From this research two alternative stories (at least) can be told, both of

79. Tom R. Tyler, Justice and Power in Civil Dispute Processing, in JUSTICE AND POWER, supra note 7 , at 309 .

80. Id. at 313 .

81. See E. Allan Lind et al., The Perception of Justice: Tort Litigants' Views of Trial, COURT-ANNEXED ARBITRATION, AND JUdiCIAL SETTLEMENT CONFERENCES (1989); E. Allan Lind et al., In the Eye of the Beholder: Tort Litigants' Evaluations of Their Experiences in the Civil Justice System, 24 LAW \& SOC'Y REV. 953 (1990).

82. Tyler, supra note 79 , at 315 .

83. See id. 
which are consistent with a constitutive theory of law's power. The first story starts from the evidence that, even for its participants, law is not solely (or perhaps even primarily) an instrumental means for achieving a desired outcome. Rather, the legal process can be a substantive end in itself. Law provides a forum for storytelling, a set of rules for constructive discourse, and a site for subjective observations about fairness. As a result, so this story goes, it is essential for achieving substantive justice that the legal system seem just and provide an effective locus for discourse. Indeed, on this view, such factors would need to be a basic part of any analysis as to what justice is.

The second, more skeptical, story challenges the first one in two significant ways. As an initial challenge, this story questions why we should think that the subjective experiences of litigants provide any truly useful information about conceptions of justice. This is because people's beliefs may reflect false consciousness. As Susan Silbey has argued, unequal power in society allows certain groups to establish hegemony in a society's ideology. By hegemony, she means "those circumstances where representations and social constructions are so embedded as to be almost invisible, so taken for granted that they 'go without saying, because, being axiomatic, they come without saying." 84 If, as Silbey contends, liberal law is hegemonic, then people's evaluations of their experiences may simply be a reproduction of a society's ideology rather than an "objective" statement of their actual interests.

A further challenge transforms the idea of procedural fairness into a view about the legitimation of power. On this view, procedural justice is not so much a worthwhile aspiration as it is a means for law to appear fair while in reality perpetuating power dynamics in the society. Indeed, Garth and Sarat question the procedural justice literature for precisely this reason: "The justice that is described in research on procedural justice is fully compatible with, and may be an essential part of, the processes through which law legitimates itself and unjust social arrangements. Thus, ... studies of procedural justice may tell us less about justice as an ideal and more about the power of law to get its way." 85

Again, I do not argue that there is anything more "correct" about the first story than the second, with its dual skeptical challenges. But notice the difference in tone and emphasis. The first story discusses the potential ways in which the justice system might actually provide a helpful forum, and might generate a sense of fairness, justice, and satisfaction through procedural or ritual mechanisms. The second story argues that, even if people gain a sense of satisfaction, their perceptions are irrelevant because

84. Silbey, supra note 14 , at 287 (quoting 1 JEAN COMAROFF \& JOHN COMAROFF, OF Revelation and Revolution: Christlanity, Colonialism, and Consciousness in South AFRICA 23 (1991)).

85. Garth \& Sarat, supra note 7 , at 11 . 
the participants are in the thrall of false consciousness and are therefore reproducing hegemonic ideologies about which they are unaware. Moreover, this story argues that the quest for procedural justice is inevitably compromised because creating the appearance of justice is merely a way of legitimating law's power.

In recent years, sociolegal scholars such as Patricia Ewick, Susan Silbey, Austin Sarat, Barbara Yngvesson, Sally Engel Merry, and David Engel have offered somewhat more optimistic variations on the idea of law as hegemony discussed above. Although they still present legal narratives as hegemonic, they insist that law is always locally contested. Accordingly, they refuse to accept a depiction of law's subjects as mere passive victims of law's power. Rather, these authors see active "agents" who may sometimes manipulate the legal system to win partial, but consequential victories, both material and symbolic. ${ }^{86}$

Yet even in these accounts, law tends to be viewed not as an enabling language that actually provides the opportunity for engagement among conflicting narratives, but as a form of power "emanating outward from the sources of sociocultural production to shape the practices of everyday life," ${ }^{87}$ and therefore allowing a space for alternative worldviews only through an act of resistance. Moreover, although disempowered people may contest the categories imposed on them by law, such contests are seen as temporary, their effects short-lived. In these analyses, law is no longer a rigid hegemony-dictating categories and determining meaning in an absolute way-but it is still viewed as a "moving hegemony." This moving hegemony "allows for the coexistence of discipline and struggle, of subjection and subversion, and directs attention toward a dynamic analysis of what it means to be caught up in power." 88 Yet, the tactical resistance of disempowered groups ultimately does not "dislodge the power of law or the dominance of legal rules and practices. ${ }^{.89}$ Indeed, "Even when relatively powerless persons adopt a counterhegemonic view of the world ... they construct it around the cultural shapes and forms that law helps to create." ${ }^{\prime 0}$ Thus, although these scholars offer a picture of law that allows for the possibility of multiple narratives, those narratives are seen as oppositional, not as inherent and empowering features of legal discourse itself. Accordingly, these accounts still tend to be framed in a suspicious language focused on exposing the inevitable and largely

86. See, e.g., EWICK \& SILBEY, supra note 21; MERRY, supra note 63; YNGVESSON, supra note 63; Austin Sarat, "...The Law is All Over": Power, Resistance, and the Legal Consciousness of the Welfare Poor, 2 YALE J. L. \& HUMAN. 343 (1990). For a discussion of this tum in sociolegal scholarship, see David M. Engel, How Does Law Matter in the Constitution of Legal Consciousness?, in How Does Law MaTTER? 109 (Bryant G. Garth \& Austin Sarat eds., 1998).

87. Engel, supra note 86, at 131.

88. YNGVESSON, supra note 63 , at 121.

89. Sarat, supra note 86 , at 376.

90. Engel, supra note 86, at 134. 
unnoticed dominance of legal categories.

Two final examples of the hermeneutics of suspicion should suffice. First, I point to the work of Pierre Schlag, even though he is not represented in the Justice and Power in Sociolegal Studies collection, because he has continued to offer a forceful critique of legal discourse from the perspective of critical legal studies. Schlag, in numerous articles and in his book The Enchantment of Reason, ${ }^{91}$ argues that judges and legal academics are trapped in a jointly constructed maze of incoherent justifications for the legal system. He contends that judges refuse to acknowledge "all that law is and all that law does" and instead insist on "a romanticized and inflated shadow image" of the law that legitimizes the inherently violent nature of legal practice..$^{92}$ Moreover, he argues that legal academics tend to perpetuate this mythology because most academics were formerly judicial clerks and so are invested in the judicial enterprise. As a consequence "of the legal academic's primal identification with the persona of the judge," ${ }^{, 93}$ Schlag concludes, legal scholarship devolves into "the legitimization and rationalization of judicial opinions." 94 Thus, Schlag argues that legal scholarship is devoted to obscuring the "real" workings of the legal system.

This perspective exemplifies the extreme skepticism of much critical sociolegal scholarship. Other scholars, working in a more realist mode, have similarly sought to demonstrate that legal doctrine is inevitably a product of political ideology by using empirical data to show that judges decide cases based on non-doctrinal factors. One recent example is Richard Revesz's work regarding the United States Court of Appeals for the D.C. Circuit. ${ }^{95}$ Revesz argues that ideology "significantly influences" judicial decision-making on the D.C. Circuit; that ideological voting is more prevalent in cases where purely procedural challenges are raised; and that a judge's vote is greatly affected by the party affiliation of the other judges sitting on the panel. ${ }^{96}$

Both Schlag and Revesz tell stories that aim to strip away the veneer covering legal doctrine, though Schlag obviously takes this critique much farther than Revesz. They view judicial decisions (and legal doctrine more generally) as a form of subterfuge, disguising law's power and the play of ideology. The story that remains untold in these accounts, of course, is the story of principled decision-making, the idea that judges strive, however

91. Pierre Schlag, The EnChantment of Reason (1998).

92. Pierre Schlag, Clerks in the Maze, 91 Mich. L. Rev. 2053, 2054 (1993).

93. Id. at 2067

94. Id. at 2063

95. Richard L. Revesz, Environmental Regulation, Ideology, and the D.C. Circuit, 83 VA. L. REV. 1717 (1997).

96. In the study, judges were assigned the party affiliation of the president who appointed them (which is, of course, in and of itself a debatable rubric for determining the ideology of any particular judge). 
imperfectly, to articulate principles in their adjudication of cases and aim to be faithful to the decisions and articulated principles of the past. This may again be a story that allows law to seem principled and therefore disguise its hegemonic power, but it is also a story that might inspire us to think of law as more than just an exercise in power politics, and thereby to look past our own parochial interest, acknowledge an opposing view, and try to develop a language for mutual accommodation and understanding. A language of principle might therefore be useful, regardless of whether or not such principles are truly determinative.

To the extent that practice of the hermeneutics of suspicion in twentiethcentury scholarship has successfully eroded notions of legal method as a science and legal rules as formalist truths, there can be little doubt that such scholarship has opened up a more varied and subtle set of inquiries and understandings about law. Moreover, much of this scholarship has been vitally important both in exposing many legal principles and procedures to be the product of hierarchy, ideology, and language, and in bringing previously unheard voices to debates about legal doctrine. Finally, the constitutive theory of law, which views law as a lens for constructing reality, holds much promise as an interpretive framework because it allows us to see the ways in which law influences both our comprehension of and discourse about social and political conflicts.

Yet, as some of the previous discussion indicates, there are also potential drawbacks to these kinds of skeptical stories, and we should be self-conscious about the ramifications of our choice to tell them. The next Part revisits the articles just discussed in an attempt to identify some of these potential drawbacks.

\section{THE HERMENEUTICS OF SUSPICION AND ITS LIMITATIONS}

I see at least two reasons to be concerned about the use of the hermeneutics of suspicion as the primary method for legal/cultural scholarship. First, the focus on unmasking a cultural practice may tend to situate the observer outside of the practice being studied, thereby robbing the observer of empathy and perhaps distorting the ultimate account. Second, oversuspiciousness may actually discourage efforts toward political change and may have a disempowering or dispiriting effect on society as a whole.

\section{A. The Importance of Empathy}

The hermeneutics of suspicion tends to place the scholarly observer in a position superior to those who are the objects of study. The skeptical critic tends to point out what is "really going on" in a particular social practice, and what is "really going on" is almost never acknowledged or understood by those who work within that practice. Indeed, because the participants are understood to be deluded by false consciousness, their perceptions and 
understandings of the world are easily discredited, or at least discounted. ${ }^{97}$

The Revesz piece provides an example. Harry T. Edwards, Chief Judge of the D.C. Circuit, wrote an article responding to Revesz's charge that the D.C. Circuit judges resolve disputes based on political ideology. ${ }^{98}$ Aside from many disagreements over Revesz's statistical analysis (which are not relevant here), Edwards argues that Revesz's work, and those by others in a similar vein, is fundamentally flawed because it treats as irrelevant the subjective experience of the judges themselves. To Edwards, "serious scholars seeking to analyze the work of the courts cannot simply ignore the internal experiences of judges as irrelevant or disingenuously expressed. The qualitative impressions of those engaged in judging must be thoughtfully considered as part of the equation." 99

Revesz's response to this charge might well be that he must discount the stated motivations of the judges. Indeed, if his attempt is to uncover the judges' "real" motivations rather than their "conscious" motivations, then the protestations of the judges are worse than irrelevant - they may actually be evidence of the judges' false consciousness!

We have already discussed this same approach with regard to the empirical studies of dispute processing. A skeptical critic might well discount a litigant's reported satisfaction with the legal system on the ground that the individual has succumbed to the illusion spun by law's embedded power. Greenhouse's reaction would likely be similar. For example, we could imagine that all those who drafted the civil rights statutes considered in her article reported that, in drafting the statutes, they were attempting to encourage diversity. We could imagine further that all the litigants who have successfully pursued claims under these statutes over the years reported that filing the suits had encouraged tolerance of diversity in their communities. Even with this testimony, it is unlikely that Greenhouse's analysis would change. And, of course, anyone attempting to refute Schlag with discussions about the importance of legal rules or principles would, in Schlag's terms, be exhibiting the very pathology that Schlag is attempting to expose.

Thus, not only is the critic situated in a position of superior perception, any objection by the participants can easily be dismissed as a product of the delusion itself. One can see how this logic operates among Ricoeur's "masters of suspicion" as well. The rhetoric of suspicion creates a dichotomy: those ensnared by false consciousness, and those who can get out from under it and see the snare. Whether this snare is deluded Christian mythologies (Nietzsche), capitalist false consciousness (Marx),

97. Note that this concern may exist regardless of whether the critic ultimately takes a position for or against the practice being studied. See supra note 20 .

98. Harry T. Edwards, Collegiality and Decision Making on the D.C. Circuit, 84 VA. L. REV. 1335 (1998).

99. Id. at 1338 . 
or repression (Freud), the basic strategy is the same. ${ }^{100}$

At first blush, it appears that postmodern critics should be able to answer this objection. Unlike the modernists, they purport not to be saying what is "really" going on beneath the surface because they believe that the interpretations are no more real than the surface behavior. ${ }^{101}$ However, the basic move is the same because the critic is able to recognize that truth is a contingent notion, while the people being discussed do not. Moreover, the view that truth is contingent tends to mean that contests about truth claims are inherently questions of politics, ideology, and power. Thus, like the skeptical critiques discussed above, most postmodern critical approaches tend to view human behavior through this lens, even while denying that any one lens is authoritative.

One might well ask, of course: Why should we be concerned that a scholarly approach tends to place the critic and reader in a position of greater perception than those working within a societal practice? After all, most of us probably have had the experience of seeing a situation more clearly with the benefit of hindsight or from a more emotionally detached perspective. Why shouldn't critics have the same privilege? My answer is that of course they should. Indeed, as I will stress later in this Essay, a less suspicious hermeneutics does not mean that critics lose their ability to be critical. Thus, there certainly may be times when a critic is able to recognize the significance of an issue that was unnoticed by the participants.

But a less suspicious, more empathetic reading has the virtue of acknowledging that the lived experience of the participants is at least relevant to the discussion. To take the Revesz/Edwards debate as an example, an empathetic hermeneutics would most certainly find it significant that judges believe themselves to be acting based on precedent and principle rather than political ideology. Indeed, only by taking the judges' belief seriously will we become aware of the possibility that the belief itself might function as a constraint on judicial discretion. Thus, judges who believe in legal principle and repeatedly tell themselves and the world a story about both the non-ideological nature of their work and the substantial constraints on their discretion may, in fact, be more constrained in their decision-making, regardless of whether or not a critic

100. See Frederick CREWS, SKePtiCal ENGAGEMENTS, at xiii (1986) ("Just as Marxism divides humankind into those people illumined by proletarian consciousness and those entrapped in capitalist false consciousness, so Freudianism can acknowledge only deep knowers-roughly, the analyzedand the repressed."). See generally JOHN FARRELL, FREUD'S PARANOID QUEST: PSYCHOANALYSIS AND MODERN SUSPICION (1996).

101. See, e.g., STANLEY FISH, Critical Self-Consciousness, or Can We Know What We're Doing?, in Doing What Comes Naturally: Change, Rhetoric, and the Practice of TheOry IN LITERARY AND LEGAL STUDIES 436, 436-67 (1989) (arguing that the theorist, because he or she inhabits a particular way of thinking and speaking, cannot ever get "outside" of a social practice in order to achieve an "objective" view). 
can "prove" that such constraints are illusory. ${ }^{102}$

As a result, less suspicious scholarship may have two benefits in this regard. First, it encourages critics both to be empathetic toward their subjects and to resist the urge to take a God's-eye view. ${ }^{103}$ Second, it forces the critic to include in the analysis the lived reality of the people being studied, leading to a richer, more textured view.

\section{B. Paranoia and the Corrosive Effects of Suspicion}

The second drawback of the hermeneutics of suspicion is perhaps even more important. As some scholars have noted, the hermeneutics of suspicion can easily slip from healthy skepticism into a kind of rhetorical paranoia. Paranoia, of course, is a loaded term, and probably a bit unfair. Nevertheless, because it is used frequently in the academic literature about the hermeneutics of suspicion, I will use it as well-though I want to make clear that I believe paranoia to be the hypothetical extreme in the movement toward skeptical scholarship. I do not mean to imply that any actual scholars necessarily display such paranoid logic.

Critics of the hermeneutics of suspicion describe the "paranoid style of functioning"104 as "an intense, sharply perceptive but narrowly focused mode of attention" that results in an attitude of "elaborate suspiciousness." 105 Paranoid individuals constantly strive to demystify appearances; they take nothing at face value because "they regard reality as an obscure dimension hidden from casual observation or participation." 106 On this vision,

The obvious is regarded as misleading and as something to be seen through. So, the paranoid style sees the world as constructed of a web of hints to hidden meaning.... The way in which the paranoid protects fragile autonomy is by insuring, or at least insisting, that the paranoid's interpretation of events is the interpretation. ${ }^{107}$

Such a paranoid style may, over time, have a potentially corrosive effect on society. ${ }^{108}$ Consider the long-term consequences of repeated exposure to suspicious stories. An appeal to religious ideals is portrayed as an exercise of political power or the result of deluded magical thinking. A

102. See, e.g., Brian C. Murchison, Law, Belief, and Bildung: The Education of Harry Edwards, 29 Hofstra L. REV. 127 (2000) (discussing the role that belief in neutral principles and the rule of law plays in the actual practice of judging).

103. See supra note 17.

104. Francis J. Mootz, The Paranoid Style in Contemporary Legal Scholarship, 31 Hous. L. REV. 873,879 (1994).

105. William Bywater, The Paranoia of Postmodernism, 14 PHIL. \& LiteratURE 79, 80 (1990).

106. Mootz, supra note 104, at 879 .

107. Bywater, supra note 105 , at 80-81.

108. See Jean Bethke Ehlshtain, Will the Real Civil Society Advocates Please Stand Up?, $75 \mathrm{CHI}$.KENT L. REV. 583, 585 (2000) (criticizing an "all-knowing skepticism [that] is skeptical about everything but skepticism"). 
canonical work of art is revealed to be the product of a patriarchal "gaze." The programs of politicians are exposed as crass maneuverings for higher office or greater power. ${ }^{109}$ The idealistic rhetoric of judicial opinions is depicted as an after-the-fact justification for the exercise of statesanctioned violence. And the life choices of individuals are shown to be responses to psychological neurosis, or social pathology.

All of these are exaggerations, but they increasingly represent the rhetoric that is used to describe human interaction both in contemporary society and in the past. As Richard Rorty describes,

In this vision, the two-hundred-year history of the United Statesindeed, the history of the European and American peoples since the Enlightenment-has been pervaded by hypocrisy and self-deception. Readers of Foucault often come away believing that no shackles have been broken in the past two hundred years: the harsh old chains have merely been replaced with slightly more comfortable ones. Heidegger describes America's success in blanketing the world with modern technology as the spread of a wasteland. Those who find Foucault and Heidegger convincing often view the United States of America as ... something we must hope will be replaced, as soon as possible, by something utterly different. ${ }^{110}$

If that is one's viewpoint, it will inevitably be difficult to muster one's energy to believe in the possibility of positive action in the world, short of revolution (and even revolution is probably inevitably compromised). As Rorty points out, though the writers of supposedly "subversive" works "honestly believe that they are serving human liberty," it may ultimately be "almost impossible to clamber back down from [these works] to a level of abstraction on which one might discuss the merits of a law, a treaty, a candidate, or a political strategy."111

Of course, one might view this as a positive development. One might think people should stop being lulled into a false sense of believing that the rhetoric of public life really matters. If people began to view such rhetoric as a construction of entrenched power, so the argument might go, they would form the nucleus of a truly revolutionary political movement.

I doubt that such an eventuality is likely to occur. Moreover, I am not sure that a culture of suspiciousness is the most effective way to seek political (or personal) change anyway. Suspicious analysis seeks to expose the dangers of our enchantment with reason or truth or collectivity, but there are dangers that arise from relentless disenchantment as well. As

109. See, e.g., JAMES Fallows, BREAKING THE NEWS: HOW THE MEDIA UNDERMINE AMERICAN DEMOCRACY 161-65 (1996) (criticizing the news media for repeatedly covering stories as if the content of political dialogue is irrelevant and only the immediate political advantage or disadvantage is worth discussing).

110. RORTY, supra note 18 , at 7.

111. Id. at 93 . 
Richard K. Sherwin has observed,

[W] ithout the means of experiencing more profound enchantments, without communal rituals and social dramas through which the culture's deepest beliefs and values may be brought to life and collectively reenacted, those beliefs ultimately lose their meaning and die.... Forms of enchantment in the service of deceit, illicit desire, and self-gratification alone must be separated out from forms of enchantment in the service of feelings, beliefs, and values that we aspire to affirm in light of the self, social, and legal realities they help to construct and maintain. ${ }^{12}$

If all we have is relentless suspicion, we are unlikely to be inspired to create a better world. Instead, we are likely to feel a kind of collective guilt and self-loathing (or worse a fatalistic apathy) because of the hopelessly compromised system we have created or to which we have acquiesced. Such guilt, self-loathing, and apathy is, as Rorty argues, a luxury that agents who need to act in the world cannot afford to maintain. ${ }^{113}$

Paul Kahn, in his recent book, The Cultural Study of Law, indirectly suggests a possible response to this critique. Kahn encourages sociolegal scholars not to worry so much about being political or social agents of the sort Rorty describes. Instead, he argues that scholars studying law as a cultural system should move "away from normative inquiries into particular reforms and toward thick description of the world of meaning that is the rule of law."114 If we resist being seduced into focusing on the policy ramifications of our work, Kahn believes, we could better study law the way a religious studies scholar studies religion: not from the perspective of one who is a part of the practice under consideration, but as an independent observer seeking to understand the cultural meaning of the practice from a greater distance. Thus, Kahn argues that it is a mistake for scholars to be too invested in legal practice, regardless of whether they see themselves as law's custodians or law's reformers. Rather, Kahn contends that we would be better off suspending our belief in law's rule altogether, ${ }^{115}$ thereby allowing us to analyze legal practice without a normative agenda.

Although I agree with Kahn that sociolegal scholarship need not include explicitly normative policy ramifications to be effective, his approach still requires the scholar to choose a hermeneutic stance. Even if we adopt the more distanced "observer" perspective Kahn advocates, we still must choose to analyze legal and cultural practices through a suspicious lens or

112. SHERWIN, supra note 38 , at 228-31.

113. See RORTY, supra note 18 , at 33 .

114. KAHN, supra note 9, at 91.

115. See id. at 3 . 
through one that is more sympathetic. And this choice inevitably has social and political consequences of the sort described above. Moreover, I am concerned about Kahn's particular articulation of the legal scholar's task: to suspend belief in law's rule. Such a formulation seems to invite a more skeptical stance than I find appropriate. Nonetheless, there is nothing about his call to study law as a cultural system rather than as a set of policy prescriptions that requires us to study law from the perspective of disbelief. Indeed, as I argue below, studying any cultural practice (whether literature or religion or law) from a perspective of belief-as long as it is not completely uncritical belief-may ultimately be more fruitful. Regardless of one's position on that issue, however, it seems to me that, at the very least, the move toward less normative scholarship cannot extricate scholars from the fundamental questions that I am discussing.

\section{A HERMENEUTICS OF MEANING, FAITH, AND SYMPATHETIC INTERPRETATION}

Ricoeur contrasts the hermeneutics of suspicion with a hermeneutics of meaning. This hermeneutics is based on a conception of faith. In Ricoeur's words, "The contrary of suspicion, I will say bluntly, is faith. What faith? No longer, to be sure, the first faith of the simple soul, but rather the second faith of one who has engaged in hermeneutics, faith that has undergone criticism, postcritical faith." ${ }^{116}$ Such faith is difficult if one employs the hermeneutics of suspicion because such a skeptical approach tends to promote "knowingness" rather than belief. Once one has exposed or demystified a cultural practice, it will inevitably be more difficult to believe in that practice whole-heartedly. One might accept it as the best of a bunch of poor alternatives, but it will lose its power to inspire.

As Rorty argues, "Knowingness is a state of soul which prevents shudders of awe. It makes one immune to romantic enthusiasm." 17 For example, he points out that it is difficult to be inspired by a cultural practice while at the same time viewing that practice "as the product of a mechanism of cultural production." 118 To view a work in this way, he contends, may yield understanding, but not self-transformation.

The hermeneutics of suspicion tends to require that the cultural practices under observation be placed within the framework of the critic. But if a practice, such as the work of the United States Supreme Court, is to have inspirational value, it must be allowed to recontextualize much of what the observer previously thought she knew; it cannot, at least at first, be itself recontextualized by what the observer already believes. ${ }^{119}$ Thus, if we

116. RICOEUR, supra note 12, at 28.

117. RICHARD RORTY, The Inspirational Value of Great Works, in ACHIEVING OUR COUNTRY, supra note 18 , at $125,126$.

118. Id. at 133 .

119. See id. 
begin with the suspicious premise that justices of the U.S. Supreme Court are articulating hopelessly indeterminate legal principles that merely mask the inevitable assertion of power inscribed within legal discourse, then we will have precluded the possibility that we could be surprised or inspired by the beauty, poetry, or idealism of the Court's project. ${ }^{120}$

But how might we fashion an alternative approach? In order to pursue one possibility, I wish to draw upon Ronald Dworkin's work on interpretation. Dworkin was writing primarily about how judges decide cases, but his approach is generalizable into a theory of interpretation that may be a useful model. Thus, for my purposes it is less important whether Dworkin accurately describes the process of judging than whether he offers a helpful metaphor through which we might consider the idea of sympathetic interpretation more generally.

Dworkin's metaphor is the chain novel. He asks us to presume a group of novelists get together and decide collectively to write a novel. One writer will contribute the first chapter, pass it on to the second writer, who will contribute the next chapter, and so on. In this scenario, "every writer but the first has the dual responsibilities of interpreting and creating because each must read all that has gone before in order to establish, in the interpretivist sense, what the novel so far created is."121

How then might, say, the writer of the sixth chapter go about interpreting the preceding five chapters? Notice that the hermeneutics of suspicion may not work very well here. Even though the author of the chapter must decide what the book is "really" about, what the motivations of the characters "really" are, and so on, it is unlikely that unmasking the descriptions provided in earlier chapters as the product of false consciousness will make a very successful novel. Similarly, if the novel through five chapters is an Agatha Christie-like mystery, the writer will be likely to refrain from turning the sixth chapter into a philosophical exegesis on the nature of human relationships. Such an approach might well make the book seem disjointed and poorly written. Notice that this is true even if the writer of the sixth chapter honestly prefers philosophical works to Agatha Christie novels. In the act of interpretation, the writer of the sixth chapter must attempt to make the overall work into the best possible work of art it can be, not transform it into a different one. As Dworkin points out, "Interpretation of a text attempts to show $i t$ as the best work of art it can be, and the pronoun insists on the difference between

120. As Rorty argues, the Foucauldian refusal to indulge in utopian thinking may not be the product of sagacity, but rather a result of Foucault's "unfortunate inability to believe in the possibility of human happiness, and his consequent inability to think of beauty as the promise of happiness." Id. at 139.

I recognize, of course, that for many the U.S. Supreme Court's decision in the recent presidential election, see Bush v. Gore, 121 S. Ct. 525 (2000), severely undermines any possibility of being inspired by the Court's work. I address this issue in a postscript to this Essay, infra.

121. RONALD DWORKIN, How Law is Like Literature, in A MATTER OF PRINCIPLE 146, 158 (1985). Dworkin uses this metaphor again in his later work, LAW's EMPIRE, supra note 19. 
explaining a work of art and changing it into a different one."122

Of course, my sixth chapter may differ from yours, because we have different ideas of what makes a work of art good. But the point is that both of us must attempt to make the work as it exists into the best work it can be. As with the Agatha Christie example above, we are not free simply to ignore the first five chapters merely because we have a very different idea of how those chapters should have been written. "An interpretation cannot make a work of art more distinguished if it makes a large part of the text irrelevant, or much of the incident accidental, or a great part of the trope or style unintegrated and answering only to independent standards of fine writing." 123

In likening this process to the act of common-law judging, Dworkin articulates an attractive theory of sympathetic interpretation:

Each judge must regard himself, in deciding the new case before him, as a partner in a complex chain enterprise of which these innumerable decisions, structures, conventions, and practices are the history; it is his job to continue that history into the future through what he does on the day. He must interpret what has gone before because he has a responsibility to advance the enterprise in hand rather than strike out in some new direction of his own. So he must determine, according to his own judgment, what the earlier decisions come to, what the point or theme of the practice so far, taken as a whole, really is. ${ }^{124}$

Again, I am not interested here in whether this is an accurate description of how judges decide cases, nor am I interested in taking sides in the longrunning scholarly debates about Dworkin's approach to interpretation. ${ }^{25}$ Instead, I want to consider Dworkin's conception solely as a thoughtexperiment that might suggest a useful attitude for scholars to adopt. Notice how this attitude differs in tone and emphasis from the hermeneutics of suspicion. For example, in Part Three of this Essay, I argued that one drawback of the suspicious approach is that it may appear to place the commentator apart from the pathologies or delusions of the people operating within a given social practice. Thus, in the act of pointing out others' "false consciousness," one implicitly exempts oneself from that consciousness. In contrast, Dworkin's model requires the interpreter to treat herself as a "partner" in the endeavor being analyzed.

Moreover, because the interpreter is in partnership with the activity or text being analyzed, she will be more likely to think of it as a joint

122. DwORKIN, supra note 121 , at 150.

123. Id.

124. Id. at 159 .

125. See, e.g., STANLEY FISH, Working on the Chain Gang: Interpretation in Law and Literature, in DoIng What Comes Naturally, supra note 101, at 87; Ronald Dworkin, My Reply to Stanley Fish (and Walter Benn Michaels): Please Don't Talk About Objectivity Any More, in THE POLITICS OF INTERPRETATION 287 (W.J.T. Mitchell ed., 1983). 
enterprise and therefore construct the best explanatory framework she can. Accordingly, she will try to understand what this enterprise amounts to and develop an interpretation that both fits the contours of the enterprise and offers the best justification for it. ${ }^{126}$ This again is very different from the hermeneutics of suspicion. A suspicious reading generally seeks to undermine the practice being studied. If one is attempting to expose, unmask, or demystify in order to show the "real" unvarnished truth, one is, by definition, not attempting to create the best justification for it or make it into the best practice it can be. To the contrary, the hermeneutics of suspicion usually seeks to show the essentially compromised nature of the practice.

Again, I want to step back from the argument for a moment, because I do not want it to be misread. I am not condemning skepticism as a critical stance altogether. Nor do I advocate merely accepting all human practices at face value without employing any critical judgment at all. It is important to recognize that, in describing the hermeneutics of meaning, Ricoeur defined it as postcritical faith, not uncritical faith.

More importantly, my aim is not to advocate that either critical stance be eradicated. Indeed, a key question that I must leave to another day is: How does one decide in any given situation which scholarly stance to take? The answer to this question is not at all clear to me, and I hope to pursue the issue in a future essay. For now, I must be content merely to open up space so that such a question can be asked. Thus, I suggest only that we examine the stories that we as scholars tend to tell and then think about whether there are others that we might tell but do not, simply because we reflexively fall into using one critical stance instead of another.

Let me use an example that is closer to home. My experience has been that, at academic conferences, reading groups or colloquia, or in humanities or law classes, much of the conversation centers on all the issues the book or article under discussion failed to address. Thus, we hear that the author left out a consideration of $X$, which would have complicated her analysis, or that she failed to recognize the ways in which issues of power were embedded in $Y$, so she missed a key part of what was "really" going on, etc. Almost inevitably, the piece that was "left out" happens to be the focus of the critic's own scholarly agenda. These are not sympathetic readings. Because human experience is widely varied and multi-faceted, there will always be aspects of an issue that are omitted in any given scholarly account. But instead of focusing on what the author failed to do, we might look at what her particular project was and see if we can form the best possible understanding of that project. I remember when I was in an undergraduate anthropology course, we would read book after book from the history of anthropological theory, and for each book,

126. See DWORKIN, supra note 19, at 228-38. 
all we would discuss was what that account had missed. By the end of the semester, I was left feeling that there were no examples of worthwhile anthropology scholarship. This is precisely what can happen if the stories we tell are unrelentingly suspicious. We deprive our listeners of a sense of inspiration, of models to follow, of belief in possibilities.

\section{A LESS SKEPTICAL APPROACH TO ThINKING ABOUT LEGAL DISCOURSE}

Having proceeded this far, I feel compelled to provide an example of a less skeptical approach to understanding legal practice in the United States. My aim here is not to lay out a complete theory, nor even to convince you that it is correct. Rather, I offer a sketch in order to suggest one possible way in which a more sympathetic story about law in American culture might be told.

One possible sympathetic story, of course, is simply to accept the status quo and argue that it should be preserved. This approach, however, might fail Ricoeur's requirement that a hermeneutics of meaning be "postcritical." In any event, I want to try something different from that. Moreover, I want to accept and adopt many of the antifoundational insights of postmodern theory, and then construct a story about legal discourse and practice in America that is aspirational.

Recently, Richard K. Sherwin's When Law Goes Pop: The Vanishing Line Between Law and Popular Culture ${ }^{127}$ has attempted a similar project. Sherwin argues (as I have earlier in this Essay) against what he calls "skeptical postmodernism." Referring to Baudrillard, Sherwin observes that skeptical postmodernism "manifests a marked inclination toward pessimism and disenchantment." 128 If truth, meaning, and reality are no longer discernible, and if any sense of the unified self or human agency is illusory, he argues, we risk living in a world where "individuals can no longer be held accountable for having 'authored' their acts or caused an event to happen." 129 According to Sherwin, "In the end the skeptical postmodern is left with nothing more than endless play and detached irony." 130

Nevertheless, like me, Sherwin refuses to jettison postmodern theory altogether. Instead, he contends, "Postmodernism need not be skeptical... A A story might concede the demise of the autonomous modern subject, but still find meaning through the distributed self: an identity made up of multiple cultural and social constructs shared by others in particular communities."131 Similarly, taking Sherwin's

\footnotetext{
127. SHERWIN, supra note 38.

128. Id. at 128.

129. Id. at 129.

130. Id.

131. Id. at 131.
} 
"affirmative postmodern" view, we might recognize that concepts such as truth and justice are contingent, but still see those ideas as coherent. "Abstraction may give way to particularity, contextuality, multiplicity; judgment may turn toward characteristic voices and localized accounts. But localization and contextualization are not fatal to meaning. It remains possible to seek rather than abandon meaning for concepts like truth and justice-even in the face of contingency, unpredictability, and spontaneity." 132

Following Sherwin's suggestion, I wish to pursue a story about law that makes no attempt to return to a formalist world where legal rules are "truths" to be "discovered" by judges. Rather, I accept the idea that there is an infinite number of possible narratives for describing reality and that each narrative is inevitably a product of many cultural forces. Further, I will accept that, at least within a certain range, none of these narratives necessarily has a stronger claim to truth than any other. In such a world, how might one understand and justify law practice in America? ${ }^{133}$

My suggestion is that we might conceive of law as a site for encounter, contestation, and play among various narratives. I draw on Hannah Arendt's conception of the "public" as a space of appearance where actors stand before others and are subject to mutual scrutiny and judgment from a plurality of perspectives. ${ }^{134}$ The public, on this view, "consists of multiple histories and perspectives relatively unfamiliar to one another, connected yet distant and irreducible to one another."135 By communicating about their differing perspectives on the social world in which they dwell together, people and communities can collectively constitute an enlarged understanding of the world. ${ }^{136}$ In this Part, therefore, I will first outline a prominent conception of "communicative democracy" that builds on Arendt, offered by political theorist Iris M. Young. Then, I will speculate about law's potential as a site for the type of idealized public discourse Young envisions. ${ }^{137}$

132. Id.

133. Sherwin sees the challenge similarly. He asks:

[I]s it possible reflectively to reframe the myth of modernity... to avoid the excesses of skeptical postmodern irrationalism and disenchantment on the one hand, and of modernist rationality and repression on the other? Put differently: how are we to affirm a world of meaning in which law and democracy may flourish?

SHERWIN, supra note 38, at 233.

134. See HANNAH ARENDT, THE Human CONDITION 50-58 (1958).

135. IRIS MARION YOUNG, INCLUSION AND DEMOCRACY 111 (2000) (discussing Arendt).

136. See ARENDT, supra note 134, at 50-58; see also LISA J. Disch, HANNAH ARENDT AND THE LIMITS OF PHILOSOPHY 80 (1994); Anna Yeatman, Justice and the Sovereign Self, in JUSTICE AND IDENTITY: ANTIPODEAN PRACTICES 195 (Margaret Wilson \& Anna Yeatman eds., 1995). For an interpretation of the Arendtian public in terms of plurality, see SUSAN BICKFORD, THE DISSONANCE OF DEMOCRACY: LISTENING, CONFLICT, AND CITIZENSHIP (1996).

137. My ultimate project, which seeks to apply theories of deliberation and discourse to legal practice, will also build upon Thomas Morawetz's application of Wittgenstein to the process of legal discourse. See Morawetz, Understanding Disagreement, supra note 16. 
In recent decades, political philosophers and legal theorists, ${ }^{138}$ drawing on the ideas of thinkers such as Arendt ${ }^{139}$ and Jürgen Habermas, ${ }^{140}$ have developed a conception of deliberative democracy as an alternative to what might be called an "interest-based" model of democracy. Using an interest-based model, democracy is seen primarily as a way of expressing one's interests and registering them in a vote. The goal of democratic decision-making, on this view, "is to decide what leaders, rules, and policies will best serve the greatest number of people, where each person defines his or her own interests." 44 As a result, democratic decisions will be the outcome of competition for self-interested votes.

Deliberative theorists, in contrast, conceive of democracy as a process that actually helps to create a public sphere. They argue:

Democratic processes [must be] oriented around discussing [a] common good rather than competing for the promotion of the private good of each. Instead of reasoning from the point of view of the private utility maximizer, through public deliberation citizens transform their preferences according to public-minded ends, and reason together about the nature of those ends and the best means to realize them. ${ }^{142}$

Building on this view, deliberative theorists attempt to define those societal settings most conducive to such public deliberation.

The vision of deliberative democracy does not necessarily mean that all debates must reach consensus or that differences of economic power, education, and cultural background must be bracketed in the search for some mythical common good. ${ }^{143}$ Indeed, as Young has argued, to the

138. See, e.g., BENJAMIN R. BARBER, STRONG DEMOCRACY: PARTICIPATORY POLITICS FOR A New Age (1984); John S. Dryzek, Discursive Democracy: Politics, Policy, and Political SCIENCE (1990); JAMES S. FISHKIN, DEMOCRACY AND DELIBERATION: NEW DIRECTIONS FOR Democratic Reform (1991); Thomas A. SPRAgENS, REASON AND DEMOCRACY (1990); James Bohman, Public Reason and Cultural Pluralism, 23 POLITICAL THEORY 253 (1995); Joshua Cohen, Deliberation and Democratic Legitimacy, in THE GOOD POLITY: NORMATIVE ANALYSIS OF THE STATE 17 (Alan Hamlin \& Philip Pettit eds., 1989); Jane J. Mansbridge, A Deliberative Theory of Interest Representation, in THE POLITICS OF INTERESTS: INTEREST GROUPS TRANSFORMED (Mark P. Patracca ed., 1992); Frank Michelman, Traces of Self-Government, 100 HARV. L. REV. 4 (1986); Cass R. Sunstein, Beyond the Republican Revival, 97 YALE L.J. 1539 (1988).

139. See generally ARENDT, supra note 134.

140. See generally Jürgen Habermas, The Structural Transformation of the Public SPHERE: AN INQUIRY INTO A CATEGORY OF BOURGEOIS SOCIETY (Thomas Burger \& Frederick Lawrence trans., MIT Press 1989) (1962); 1 JÜRGEN HABERMAS, THE THEORY OF COMMUNICATIVE ACTION: REASON AND THE RATIONALIZATION OF SOCIETY (Thomas McCarthy trans., Beacon Press 1984) (1984); Jürgen Habermas, Three Normative Models of Democracy, in DEMOCRACY AND DifFERENCE: CONTESTING THE BOUNDARIES OF THE POLITICAL 21 (Seyla Benhabib ed., 1996).

141. Iris Marion Young, Communication and the Other: Beyond Deliberative Democracy, in DEMOCRACY AND DIFFERENCE, supra note 140, at 120, 120.

142. Id. at 121 .

143. See generally James Bohman, Public Deliberation: PluRalism, Complexity, AND DEMOCRACY (1996) (criticizing communitarian and neo-republican interpretations of deliberation as requiring too much consensus). 
extent that deliberative theorists may have overemphasized such requirements, we might adjust this model so that it is less about deliberation toward consensus, and more about communication across differences. Indeed, Young points out, one of the problems of focusing on consensus is that

such a conception cannot account well for the transformation the communicative process should often produce in the opinions of the participants. If we are all looking for what we have in commonwhether as a prior condition or as a result-then we are not transforming our point of view. ${ }^{144}$

Accordingly, she calls her alternative conception a model of communicative, rather than deliberative, democracy.

Young's conception of communicative democracy may be particularly useful in helping to articulate a generative vision of law. She views the goal of democratic discourse to be the process of encountering differences of meaning, social position, language, background, and perspective. Inclusion of multiple points of view is obviously important because it is a means of demonstrating equal respect for those views. But, Young argues, the inclusion of multiple voices serves two other important functions as well: "First, it motivates participants in political debate to transform their claims from mere expressions of self-regarding interest to appeals to justice. Second, it maximizes the social knowledge available to a democratic public, such that citizens are more likely to make just and wise decisions." ${ }^{145}$ Both functions are deserving of further consideration.

As to the first, Young argues that, when a debate includes multiple voices, we must each pursue discourse that is not framed in the rhetoric of pure self-interest. "Because others are not likely to accept 'I want this' or 'This policy is in my interest' as reasons to accept a proposal, the requirement that discussion participants try to make their claims understandable and persuasive to others means they must frame the proposals in terms of justice." ${ }^{146}$ This does not mean, of course, that others will necessarily agree with the justice claim, but nevertheless, at least on a rhetorical level, the claim must be framed from a broader point of view. Because such a view must take into account a range of socially differentiated perspectives, we are forced to recognize that our own perspective is merely one among many. "Listening to those differently situated than myself and my close associates teaches me how my situation looks to them, in what relation they think I stand to them."147 This acknowledgment of multiple stories is particularly important for those

144. Young, supra note 141 , at 127.

145. YoUNG, supra note 135 , at 115.

146. Id.

147. Id. at 116 . 
with more power in society:

Those in structurally superior positions not only take their experience, preferences, and opinions to be general, uncontroversial, ordinary, and even an expression of suffering or disadvantage . . . but also have the power to represent these as general norms. Having to answer to others who speak from different, less privileged, perspectives on their social relations exposes their partiality and relative blindness. ${ }^{148}$

Thus, the requirement that people speak in a language that acknowledges multiplicity may help moderate some of the normalizing tendencies of dominant discourse.

As to the second function, Young argues that including multiple points of view not only has the potential to alter the rhetoric of public discourse, but also provides an opportunity to gain knowledge about a broader crosssection of society. People in differentiated social positions may have (1) different understandings of their social position in relation to others; (2) a particular point of view about the perspectives of others; (3) a unique understanding of their society's history; (4) a distinctive conception of "how the relations and processes of the whole society operate"; and (5) a position-specific narrative about the natural and physical environment. ${ }^{149}$ As a result, if people are going to address collective problems, they must acknowledge and embrace each other's perspective and thereby recognize their own perspective as only partial. "Such an enlarged view better enables them to arrive at wise and just solutions to collective problems to the extent that they are committed to doing so."150

Having briefly sketched a scenario for ideal communicative democracy, the question now is whether we can tell a story about legal practice that envisions legal discourse and procedure as a potential site for such communication. I believe such a generative story is available.

To begin, there can be little doubt that law, at least as practiced in this country, holds a privileged place as a forum for addressing social and political issues. Indeed, de Tocqueville's famous observation that " $[\mathrm{s}]$ carcely any political question arises in the United States that is not resolved, sooner or later, into a judicial question"151 has been repeated so often that it has itself become a part of our national lore. Moreover, the pervasive presence of law in American society grew still greater in the

148. Id:; see also Martha Minow, Making All the Difference: Inclusion, Exclusion, AND AMERICAN LAW (1990) (discussing the importance of multiple perspectives as a means of dislodging stated assumptions about social relations).

149. See YOUNG, supra note 135 , at 117.

150. Id. at 118 .

151. 1 Alexis de TocQueville, Democracy IN AMERICA 280 (Phillips Bradley ed., Henry Reeve trans., Vintage Classics 1990) (1835). 
twentieth century, penetrating more spheres of social and domestic life. ${ }^{152}$ The century saw the enfranchisement of women and the enforcement of civil rights protections for African Americans. In addition, we witnessed the establishment of public defender offices to represent criminal defendants, the expansion of the Bill of Rights to cover a range of police procedures and prison conditions, and the creation of an income tax law, bank deposit insurance laws, social security laws, and regulatory laws aimed at everything from environmental protection to the filing of corporate financial statements. Government agencies dispatched agents around the country to enforce legal rights and duties. Litigation among business corporations grew rapidly, ${ }^{153}$ and the size of law firms serving corporate clients increased as well. ${ }^{154}$ By the end of the twentieth century, the threat of legal liability permeated the operation of universities, public school systems, hospitals, and municipal governments, as well as tobacco companies, land developers, and product manufacturers. Perhaps most significantly, ordinary individuals increasingly came to think of themselves as possessing legal rights and therefore defined "the law" not only as a range of official demands and constraints, but as a universally available set of entitlements. ${ }^{155}$

Thus, we can see that, throughout the twentieth century, de Tocqueville's observation remained accurate. From the Scopes monkey trial to the trial of O.J. Simpson, from the national debate over abortion to the more recent clashes over doctor-assisted suicide, from the success of novelist John Grisham to the explosion of law shows on television, our national obsession with law appears to have continued unabated. And, even though lawyers are often objects of derision, when the chips are down, we Americans are apt to frame our struggles in the language of competing rights and fight our battles in a legal forum. ${ }^{156}$

This forum could be envisioned to be a model for multivocal discourse of the sort Young advocates. Indeed, law is a social practice that both recognizes the existence of many different narratives and provides the opportunity to create new narratives that may help forge group

152. The examples in this paragraph are drawn from a useful discussion of law in twentiethcentury America found in Robert Kagan, Bryant Garth \& Austin Sarat, Facilitating and Domesticating Change: Democracy, Capitalism, and Law's Double Role in the Twentieth Century, in LookING BACK AT LAW's CENTURY (Robert Kagan et al. eds., forthcoming 2001) (manuscript at 7-8, on file with author).

153. See, e.g., William Nelson, Contract Litigation and the Elite Bar in New York City, 19601980, 39 EMORY L.J. 413 (1990).

154. See, e.g., Marc Galanter \& Thomas Palay, Tournament of Lawyers: The TRANSFORMATIONS OF THE BIG LAW FIRMS (1991).

155. See generally EWICK \& SILBEY, supra note 21.

156. Whatever one might think about the role of the courts in the presidential election of 2000 , there can be little doubt that the post-election contest is a testament to the extraordinary willingness of Americans to wage political battles in a legal forum. For a discussion of how the ideas in this Essay relate to the election and its aftermath, see Postscript, infra. 
identities. ${ }^{157}$ Legal proceedings, therefore, function in part as a site for adjudicating among various explanatory narratives for describing reality. ${ }^{158}$

Both trials and judicial opinions, for example, ultimately construct a narrative about a disputed event by rendering a decision or verdict. They do so, however, only after first enacting a performance in which the society "creates, tests, changes, and judges" the various competing discourses that could make up our social knowledge. ${ }^{159}$ As James Boyd White has observed,

The judicial process not only recognizes the individual but compels him to recognize others. For the litigant, the lawyer, and the observer alike, the central ethical and social meaning of the practice of the adversary hearing is its perpetual lesson that there is always another side to the story, that yours is not the only point of view. ${ }^{160}$

On this view, law's strength is precisely in its ability to provide a forum for testing the persuasive power of competing narratives:

The multiplicity of readings that the law permits is not its weakness, but its strength, for it is this that makes room for different voices, and gives a purchase by which culture may be modified in response to the demands of circumstance. It is a method at once for the recognition of others, for the acknowledgment of ignorance, and for cultural change. ${ }^{161}$

In its ideal state, therefore, law provides a set of institutions that emphasize the fact that "we are a discoursing community, committed to talking with each other about our differences of perception, feeling, and value, our differences of language and experience."162

Consider, for example, the paradigmatic exchange between teacher and student in a first-year law school classroom. The student has an initial reaction to a case or an issue. Immediately, that student is forced to confront multiple alternative narratives for understanding the question. For example, the student might be asked to consider a less sympathetic set of facts, or to argue the issue from the opposing party's point of view. Or the

157. See Reva B. Siegel, Collective Memory and the Nineteenth Amendment: Reasoning About "the Woman Question" in the Discourse of Sex Discrimination, in HISTORY, MEMORY, AND THE LAW, 131, 133-34 (Austin Sarat \& Thomas R. Kearns eds., 1999).

158. See Cover, Nomos and Narrative, supra note 15; see also Paul Schiff Berman, An Observation and a Strange But True "Tale": What Might the Historical Trials of Animals Tell Us About the Transformative Potential of Law in American Culture?, 52 HASTINGS L.J. 123 (2000).

159. Robert Hariman, Performing the Laws: Popular Trials and Social Knowledge, in POPULAR TRIALS: RHETORIC, MASS MEDIA, AND THE LAW 17, 29 (Robert Hariman ed., 1990).

160. JaMEs Boyd White, Justice as TRANSLATION: AN ESSAY IN Cultural and LEgaL CRITICISM 266 (1990).

161. James Boyd White, Law as Language: Reading Law and Reading Literature, 60 TEX. L. REV. 415, 444 (1982).

162. WHITE, supra note 160 , at 80 . 
student might be forced to address the question from the perspective of law and economics, or critical legal studies. The teacher might point out the historical reasons the law evolved in a contrary fashion. Ultimately, the debate might include questions of public policy, judicial competence, the appropriate division of responsibility among branches of government, and the practical impediments to reaching a solution. In the end, the student is encouraged to develop a more nuanced viewpoint, one that takes greater account of all the various available narratives on the issue. At its best, this process should be a lesson in tolerance for opposing viewpoints, an exercise in humility. The student can develop a greater understanding and appreciation for other ways of conceptualizing issues. From this idealized exchange, we can envision law as a "method of individual and collective self-education, a way in which we teach ourselves, over and over again, how little we can foresee, how much we depend on others, and how important to us are the practices we have inherited from the past."163

Thus, we can perhaps tell a story of law as a useful site for discourse among multiple worldviews. And when we think of law in this way, we need not be limited to the idea that law is only the official discourse that takes place in courtrooms and legal memoranda. Rather, as the constitutive view makes clear, law talk is dispersed throughout the culture-in the newspaper accounts of legal decisions, in the everyday conversations that invoke conceptions of legal rights, and in the way law is portrayed in movies, on television, and in books. ${ }^{164}$ Accordingly, law is not simply a form of pervasive hegemonic control dictated and managed by elites. We are all continuously producers and consumers of our legal culture, and the story is always in flux. Moreover, all of these multiple understandings and perspectives can be seen as an inevitable part of the language of justice, not simply as a set of stories generated in opposition to law's power. ${ }^{165}$ As one commentator has pointed out, "justice... involves reconciling diversities into a restored and new multiple unity. Justice requires a unity of differences; mutuality and incorporation rather than annihilation of opposites and distinctions." 166

Such a unity is always provisional, always contingent, always contested. As Sherwin observes,

It is precisely the proximity of disorder-deriving from constant contestation among conflicting discourse communities as well as from the various irrational forces that surround and suffuse them-

163. Id. at 266.

164. See supra note 21.

165. This distinction may be why the view of law I suggest is different from the focus of some sociolegal studies of "agency"- the ways in which individuals resist law. See supra notes 86-90 and accompanying text.

166. Jane Flax, The Play of Justice, in Disputed SubJECTS: ESSAYS ON PSYCHOANALYSIS, POLITICS AND PHILOSOPHY 111, 123-24 (1993). 
that compels new forms of legal self-organization. ... This is how law adapts to the contingencies and vicissitudes of shifting social, cultural, and technological (among other) developments. ${ }^{167}$

In the end, law's generative potential in American culture rests on its availability as a site for continuous self-criticism and re-creation. And the effort to articulate principles of justice, the creation of fora for debating those principles, the commitment to a culture of conversation about them, and the recognition that clashes among various forms of knowledge are inevitable and desirable - these are the aspects of law we might want to celebrate, tell stories about, and strive to achieve.

These stories about law strike me as particularly important ones for those of us within the legal academy to communicate to our students. Law professors and students have long wrestled with the issue of why so many students enter law school with a strong sense of idealism about law and a clear set of intuitive personal values, only to lose their grip on both during the first year of law school. This process is often derisively referred to as "learning to think like a lawyer," and is treated as synonymous with being forced to abandon one's own sense of moral truth. It strikes me that the disillusionment many feel during the first year of law school arises because students are forced to acknowledge that, on any given issue, there are multiple competing views, many of which are valid even if one does not agree with them. Thus, students are having their preconceptions or prejudices challenged. Such challenges are useful, but professors are often content merely to challenge; we do not take the next step, which is to show students that there is an independent ethical value in trying always to see and respect multiple points of view. Thus, the oft-criticized willingness of lawyers to espouse any point of view regardless of personal belief does not necessarily signal a cynical lack of conviction. Rather, it is an acknowledgment that all points of view deserve to be aired. It is a recognition that human truths are contingent, that it is always possible to use many different narratives to describe any single event. Indeed, one might even say that the very language and structure of our legal processes are premised on the idea of a discourse among multiple worldviews. Learning to think like a lawyer is, ideally, a lesson in tolerant, creative, civic discourse.

This is, of course, merely a sketch of a more systematic analysis of law in American culture that must await future elaboration. However, even this brief account may offer a sense of what a less skeptical approach to legal/cultural analysis might look like. I also realize that my vision of law as a potentially generative cultural practice is an idealistic one and that there are many objections that could be made. For example, it could be argued that official legal discourse, far from embracing multiple points of

167. SHERWIN, supra note 38 , at 238-39. 
view, is severely limited by formal rules, ${ }^{168}$ and actually distorts alternative stories or shuts them out altogether by privileging only certain types of rhetoric, which must be spoken by an elite, trained, professional class. ${ }^{169}$ Moreover, even the legal norms that tend to conflate discussion with argument may tend to mute certain types of voices. ${ }^{170}$ These objections are significant, and any generative story about law requires that we not accept legal discourse uncritically.

Nevertheless, the idealized story still plays an important role. In a less skeptical approach to conceptualizing legal discourse and practice it is essential for us to look at law, not as it exists in any particular place and time, but "as a collective activity of mind and spirit, which has the possibility of goodness, of value, even of greatness." to that expressed by James Boyd White:

[I] $\mathrm{t}$ is with the possibility, not the often lamentable current conditions, that I am concerned. Perhaps I am answering a voice, in myself or in the culture, that says that there is no such possibility; that law is only the exercise of power by one person or group over another, or only a branch of bureaucracy, or only money-making, or only instrumental; that it has no real and independent value for the person or the community. Thus I ask whether we can imagine law as an activity that in its ideal form, at least on occasions, has true intellectual, imaginative, ethical, and political worth. If we can, this would give us both something to aim for and a more workable and trustworthy ground for the criticism of what we see around us. ${ }^{172}$

Moreover, the vision must be idealistic because we need stories to tell that offer hope for the future and a goal to achieve. ${ }^{173}$ As academics we

168. For example, critical race theorists, feminists, and others have advocated relaxing the rules of evidence to encourage narrative testimony. See, e.g., Jacqueline St. Joan, Law and Literature: Sex, Sense, and Sensibility: Trespassing Into the Culture of Domestic Abuse, 20 HARV. WOMEN's L.J. 263, 266 (1997) (arguing that "rules of evidence and the interrogatory format of the trial process suppress the female voice," and suggesting that a remedy to the problem lies in "broadening the scope of judicial inquiry at trial and loosening the restrictions on narrative-style testimony"); Kathryn Abrams, Hearing the Call of Stories, 79 CAL. L. REV. 971 (1991); Richard Delgado, Storytelling for Oppositionists and Others: A Plea for Narrative, 87 MICH. L. REV. 2411 (1988); Lynne N. Henderson, Legality and Empathy, $85 \mathrm{MICH}$. L. REV. 1574 (1987); Martha Minow, When Difference Has Its Home: Group Homes for the Mentally Retarded, Equal Protection, and Legal Treatment of Difference, 22 HARV. C.R.-C.L. L. REV. 111 (1987). Many other sources are collected in Barbara J. Flagg, The Algebra of Pluralism: Subjective Experience as a Constitutional Variable, 47 VAND. L. REV. 273 (1994).

169. See, e.g., Lucy E. White, Subordination, Rhetorical Survival Skills, and Sunday Shoes: Notes on Hearing of Mrs. G., 38 BufF. L. REV. 1 (1990).

170. See, e.g., Marianne Constable, Reflections on Law as a Profession of Words, in JUSTICE AND POWER, supra note 7, at 19.

171. Milner S. Ball \& James B. White, A Conversation Between Milner Ball and James Boyd White, 8 YALE J.L. \& HuMAN. 465, 468 (1996).

172. Id.

173. See RORTY, supra note 117 , at 140 (describing the divide "between people taking refuge in self-protective knowingness about the present and romantic utopians trying to imagine a better 
need not gloss over injustice, nor accept the status quo blindly or uncritically. But we are responsible for the stories we choose to tell. We can choose to understand the efforts of our fellow human beings sympathetically or cynically. We can see our country as a fallen nation that is irredeemably corrupt, or we can describe it in terms we passionately hope it will embody. We can view our society as inevitably divided by class, race, ethnicity, gender, and ideology, or we can search for stories that help us see a shared enterprise. As postmodern theory has made us understand, the narrative we tell is not truth; it is a choice. I believe it is a choice we should make solemnly and with full understanding of both the power and potential of our tales.

\section{POSTSCRIPT}

Although this Essay was written prior to the events surrounding the presidential election of 2000 , the ideas I explore seem particularly pressing in light of the legal controversy over ballots in Florida and the disillusionment that many feel about the U.S. Supreme Court's role in the outcome. The news coverage of the ongoing court battles demonstrated just how far the hermeneutics of suspicion have pervaded popular culture, at least with respect to the legal system. Indeed, for a full month nearly every mention of a court or a judge was accompanied with a phrase identifying the purported political make-up of the court or the presumed party affiliation of the judge. Thus, the media sent a clear message: Regardless of what judges say or what the ideals of the justice system demand, the courtroom is simply another partisan political forum where people vote their ideological preferences. Unfortunately, the U.S. Supreme Court's ultimate decision did little to temper this suspicious attitude. Fundamentally flawed as a matter of both logic and jurisprudence, the opinion of the narrow five-member majority is difficult to explain on any grounds other than partisanship.

The result of all this is that any faith we may have had in our legal institutions as a place where we struggle, however imperfectly, to articulate useful principles for living together or attempt to engage in constructive dialogue has been sorely tested. As one commentator has noted, it is possible that, especially in the wake of the election, "we're all 'crits' now." 174

So how do I, as one who has argued for the generative potential of law in American culture, respond to Bush v. Gore? ${ }^{175}$ First of all, I reject the assumption that the partisan nature of this decision simply made manifest that which is present in every judicial decision. The actions of five justices

future").

174. Jeremy Paul, We're All Crits Now, 26 LAW \& Soc. INQUIRY (forthcoming 2001).

175. 121 S. Ct. $525(2000)$. 
in a truly anomalous case cannot be allowed to speak for the work of the entire judiciary around the nation. Second, I reiterate that the optimistic vision I have begun to articulate here is an aspiration and therefore, by definition, is not always fulfilled. Nevertheless (and perhaps this is the most important point of my Essay), an ideal does not lose its value simply because human beings inevitably fall short of it. Indeed, even if we know in advance that it cannot be reached, we might be better off with the ideal than without it. Both our willingness to believe in the ideal and our dedication in striving toward it may, by themselves, encourage us to create better social institutions. And, if even one person who was unheard by the political process can gain a forum for change through the legal system, that is a miracle that cannot be sloughed off as inconsequential. We can certainly decry injustice or disingenuousness in our legal system, but I think we should resist the temptation to insist cynically that justice is not possible or is an incoherent category altogether. Rather, we might wish to remember the little miracles and continue to insist on the possibility of possibility. 
